\title{
Review
}

\section{Sharks senses and shark repellents}

\section{Nathan S. HART and Shaun P. COLLIN}

School of Animal Biology and the Oceans Institute, The University of Western Australia,

Crawley, Perth, Australia

Correspondence: Nathan Hart, School of Animal Biology (M317) and the Oceans Institute,

The University of Western Australia, Crawley, Perth WA6009, Australia

Email: nathan.hart@uwa.edu.au

Running title: Sharks senses and shark repellents

This article has been accepted for publication and undergone full peer review but has not been through the copyediting, typesetting, pagination and proofreading process, which may lead to differences between this version and the Version of Record. Please cite this article as doi: 10.1111/1749-4877.12095. 


\begin{abstract}
Despite over 70 years of research on shark repellents, few practical and reliable solutions to prevent shark attacks on humans or reduce shark bycatch and depredation in commercial fisheries have been developed. In large part, this deficiency stems from a lack of fundamental knowledge of the sensory cues that drive predatory behavior in sharks. However, the widespread use of shark repellents is also hampered by the physical constraints and technical or logistical difficulties of deploying substances or devices in an open-water marine environment to prevent an unpredictable interaction with a complex animal. Here, we summarise the key attributes of the various sensory systems of sharks and highlight residual knowledge gaps that are relevant to the development of effective shark repellents. We also review the most recent advances in shark repellent technology within the broader historical context of research on shark repellents and shark sensory systems. We conclude with suggestions for future research that may enhance the efficacy of shark repellent devices, in particular, the continued need for basic research on shark sensory biology and the use of a multi-sensory approach when developing or deploying shark repellent technology.
\end{abstract}

Key words: sensory biology, sharks, shark depredation, shark repellents 


\section{INTRODUCTION}

"Many shark experts believe that an important answer to the shark hazard will be a greater appreciation of the shark by man...when more men learn to savour its flesh and more men are shod with its leather, the shark will be regarded as an asset and fished for more extensively, and in doing so, as meshing has proved, the hazard will be greatly reduced. How fortunate that this solution can not only unveil an important untapped natural resource, but also reduce the numbers and therefore the dangers from sharks." Gilbert \& Gilbert (1973)

Perry and Claire Gilbert's statement was made at a time when sharks were largely considered a nuisance by commercial fishermen and were not yet hunted on an industrial scale for their flesh, skin, cartilage, jaws, liver oil and fins. Moreover, the future ecological impacts of the massive quantities of shark bycatch that occur in present day commercial fisheries (ca. 32 million sharks annually, Worm et al. 2013) were not appreciated. Rather, the focus of research on shark repellents was the protection of human life. Today, sharks are increasingly seen as vulnerable to overexploitation due to their slow growth rate, late age of maturity, long gestation period, and low reproductive output. Even one of the most prolific and resilient of shark species, the blue shark (Prionace glauca Linnaeus, 1758), which accounts for at least $15 \%(\sim 11$ million sharks) of the present day total annual shark catch ( $\sim 63$ million sharks) is already caught at a rate beyond its likely Maximum Sustainable Yield (Clarke et al. 2006; Worm et al. 2013).

While the need for cheap and effective shark repellents for use by divers, swimmers, surfers and other water sports enthusiasts remains strong, the need to develop ways to reduce shark bycatch and depredation in commercial fisheries is now equally important. These two goals may require different configurations of the same technology, but both are based on the basic neurobiology of the shark's sensory systems and their influence on behavior. A spate of fatal shark bites in Australia during 2011-12 has renewed interest in the development of shark repellents to protect human life, but other discoveries in recent years have generated new possibilities for bycatch reduction devices that 
protect the lives of sharks. It is, therefore, timely to review the progress that has been made within the broader context of research on shark repellents over the last 70 years (such that the wheel is not reinvented) and to identify future directions for the development of shark repellents and for filling the gaps in our understanding of the sensory abilities of sharks, on which the success of any new repellent technology depends.

\section{AN OVERVIEW OF SHARK SENSORY ABILITIES}

Sharks possess an impressive array of highly specialized sensory systems that have been shaped by over 400 million years of evolution. Each sensory modality allows the shark to detect and respond to a different set of biotic and/or abiotic stimuli within its immediate environment and over different spatial scales. The possession of multiple functionally distinct sensory systems not only provides redundancy when conditions are such that one or more senses are unusable, (e.g., electroreception may be used instead of vision to find prey in turbid water or at night), but also increases the chances that a given stimulus or object will be detected and/or correctly identified (Stein et al. 2005).

A detailed knowledge of the sensory biology of sharks is essential for understanding the ways in which sharks interpret the world around them and, therefore, how their behavior can be manipulated. In the following section, we provide a condensed overview of the various sensory systems of sharks with greatest emphasis placed on the capabilities and thresholds of each sensory modality, rather than dwelling on functional mechanisms, as detection abilities are most pertinent for the development of shark repellents.

\section{Vision}

As a group, sharks have well-developed eyes and display interspecific variations in eye structure that reflect adaptations for vision in different photic environments, ranging from the darkness of the deep-sea to brightly lit surface waters (for recent reviews, see Hart et al. 2006; Lisney et al. 2012). Many sharks, especially those inhabiting shallow and brightly lit waters, have large eyes capable of providing a detailed image of their surroundings (Lisney \& Collin 2007). Their visual acuity (spatial resolving power) is comparable to that of other marine vertebrates,such as teleost fishes (Collin \& Pettigrew 1989; Fritsches et al. 2003) and marine mammals (Mass \& Supin 2002; Hanke et 
al. 2009), and ranges from $\sim 2$ to $\sim 11$ cycles per degree (Hueter 1990; Lisney \& Collin 2008; Theiss $e t$ al. 2010). The lateral position of the eyes in the head affords a cyclopean visual field of $360^{\circ}$ in the vertical plane and between $308^{\circ}$ and $338^{\circ}$ in the horizontal plane, with varying degrees of binocular overlap in the dorsal $\left(4^{\circ}-9^{\circ}\right)$, ventral $\left(6^{\circ}-15^{\circ}\right)$, and frontal visual axes $\left(10^{\circ}-48^{\circ}\right)$ (Harris 1965; McComb et al. 2009).

With the exception of some deep water species that are thought to possess an all-rod retina (e.g., Bozzano et al. 2001), most sharks studied to date have a duplex retina containing both rod and cone photoreceptors and, therefore, are capable of using vision over a wide range of light intensities (Schaper 1899; Gruber et al. 1975; Litherland \& Collin 2008; Schieber et al. 2012). As with other vertebrates (Walls 1963), the relative proportions of rod and cone photoreceptors in the retina of a given species of shark tends to reflect the relative intensity of light in its habitat, with the highly sensitive rod photoreceptors far more abundant in species that are predominantly active at night or in deep water compared to those that are shallow dwelling and more diurnal in habit (Hart et al. 2006).

The wavelength of peak sensitivity $\left(\lambda_{\max }\right)$ of the visual pigment expressed in the rod photoreceptors ranges from $472 \mathrm{~nm}$ in the Portuguese dogfish (Centroscymnus coelolepis Barbosa du Bocage \& de Brito Capello, 1864)(Denton \& Shaw 1963) to $518 \mathrm{~nm}$ in the bull shark (Carcharhinus leucas Müller \& Henle, 1839)(Hart et al. 2011). As with teleost fishes (Denton \& Warren 1957; Munz 1958) and marine mammals (Lythgoe \& Dartnall 1970; McFarland 1971), shark species that inhabit deeper water tend to have rod pigment $\lambda_{\max }$ values that are shifted toward shorter wavelengths to match the restricted spectrum of light available at depth (Crescitelli et al. 1985; Crescitelli 1990).

In addition to a single spectral type of rod, only one spectral type of cone visual pigment has been measured in sharks: the $\lambda_{\max }$ of the cone pigment ranges from $532 \mathrm{~nm}$ in the blacktip shark (Carcharhinus limbatus Müller \& Henle, 1839) to $561 \mathrm{~nm}$ in the ornate wobbegong shark (Orectolobus ornatus De Vis, 1883)(Hart et al. 2011; Theiss et al. 2012b). Although visual pigments have been characterised in very few of the more than 500 described species of shark (Last \& Stevens 2009), based on the diversity of the species studied it seems likely that cone monochromacy is widespread throughout the taxon. This is perhaps surprising given the presence of multiple spectral 
types of cone in the retinas of rays (Hart et al. 2004; Theiss et al. 2007; Van-Eyk et al. 2011) that inhabit similar photic environments and at least one species of chimaera (Davies et al. 2009).

Whilst cone monochromacy on land is rare, it appears to be relatively common in the marine environment: whales, dolphins and seals also possess only a single medium-wavelength-sensitive cone pigment (Crognale et al. 1998; Peichl et al. 2001; Newman \& Robinson 2005). The implication for both sharks and marine mammals is that, at best, they have only a rudimentary color vision system based on the comparison of signals from rods and cones (which differ slightly in spectral sensitivity) and, at worst, lack color vision altogether. Behavioral evidence for color vision in both sharks (Gruber 1975; Cohen 1980) and marine mammals is equivocal (Madsen 1976; Wartzok \& McCormick 1978; Griebel \& Schmid 1992, 2002). However, it seems likely that for both taxa, brightness contrast rather than color is likely to play a primary role in the detection and discrimination of ecologically relevant objects, such as predators, prey, and conspecifics.

In addition to brightness contrast, the visual detection of motion is probably critical to many shark behaviors. Unfortunately, very little is known about motion vision in elasmobranchs. Sharks display compensatory eye movements during swimming that serve to stabilize the image on the retina as the head oscillates from side-to-side, but this vestibulo-ocular reflex is driven by inertial motion detectors in the inner ear rather than visual input (Harris 1965; Paulin \& Montgomery 1986). However, the accessory optic system of sharks, which also aids in gaze stabilization by generating eye movements that correct for self-motion, is driven by visual input (Masseck \& Hoffmann 2008). Although only a single species of shark has been studied (the small-spotted catshark, Scyliorhinus canicula Linnaeus, 1758), it appears that the accessory optic system of sharks is atypical. In contrast to teleosts and tetrapods, the retinorecipient direction-selective neurons in the pretectum that detect large-field image motion caused by body rotations are broadly tuned in terms of preferred direction, are not inhibited by motion in the opposite (null) direction, and do not translate onto a vestibular or extra-ocular muscle reference frame (Masseck \& Hoffmann 2008, 2009). The behavioral significance of this unusual arrangement is unclear.

There are, as yet, no direct studies on the ability of sharks to detect small object motion, which would be relevant to the detection of a prey item against the background (Eckert \& Zeil 2001). 
However, the ability to detect temporal changes in image brightness alone is often used as a proxy for the ability to detect object motion (e.g., Fritsches et al. 2005), largely because visual motion cues are derived from spatiotemporally correlated variations in retinal image brightness (Reichardt 1961; Clifford \& Ibbotson 2002). One measure of temporal resolution is the critical flicker fusion frequency (cFFF), which is the frequency at which a flickering light stimulus appears continuous to the observer. Photopic (i.e. light-adapted) cFFFs reported for various shark species range from 10 to $36 \mathrm{~Hz}$ (O'Gower \& Mathewson 1967; McFarland 1990; McComb et al. 2010), which falls at the bottom end of the range measured in teleost fishes (McFarland \& Loew 1983; Horodysky et al. 2008) but implies that they are likely to be able to detect reasonably fast object motion. Studies in a range of vertebrates have established that the frequency at which the visual system is most sensitive to changes in image brightness is typically around $15 \%$ of the photopic cFFF (McFarland \& Loew 1983), which would suggest that, although capable of responding to higher rates, sharks are most sensitive to flicker in the $1-5 \mathrm{~Hz}$ range.

\section{Hearing}

The inner ears of shark are similar in morphology to those of other gnathostomes and comprise a membranous labyrinth consisting of three orthogonally arranged, fluid-filled semicircular canals and three otolithic organs: the sacculus, utriculus, and lagena (Retzius 1881; Maisey 2001). Sensory hair cells that respond to mechanical deflection with graded electrical potentials (Hudspeth \& Corey 1977) are located on a ridge (crista ampullaris) in a swelling (ampulla) at the base of each semicircular canal and in a sensory epithelium (macula) on the wall of each otolithic organ (Tester et al. 1972). An additional sensory end organ, the macula neglecta, is located on the wall of the posterior canal duct (Corwin 1977). The hair bundles of sensory cells in the ampullae, macula neglecta and otolithic organs are embedded within a gelatinous mucopolysaccharide matrix or 'cupula'; in the case of the otolithic organs, the matrix also contains an aggregation of endogenous calcareous mineral granules (Carlström 1963; Tester et al. 1972) and/or exogenous sand particles (Lychakov et al. 2000; Mills et al. 2011) that form a denser otoconial mass. 
Unlike many bony fishes, sharks do not possess swim bladders or other structures that can convert acoustic pressure into a displacement stimulus and are, therefore, thought to be able to respond only to the particle motion component of sound (acceleration, velocity, or displacement) and not the pressure component, although this remains to be demonstrated conclusively (Nelson 1967; Gardiner et al. 2012). The sensory structures of the inner ear function as accelerometers that respond to both self-induced motion and displacements produced by external sources. As in other vertebrates, the semicircular canals are responsible for detecting rotational and translational movements of the head, and the otolithic organs detect linear acceleration caused by self-motion and the action of gravity. When a shark moves its head, the inertial lag of the endolymph filling the semicircular canals deflects the cupula of the crista ampullaris and, consequently, the hair bundles of the underlying sensory epithelium (Popper et al. 2003). Similarly, the inertial lag of the otoconial mass provides a stimulus for the macular hair cells under the effects of gravity or head movements. Thus, the inner ear is primarily and evolutionarily a motion detector, and is an essential part of the vestibular system that controls posture and balance (Ladich \& Popper 2004).

Sound detection in elasmobranchs is thought to occur through two mechanisms, one mediated by the otolithic organs and the other involving the macula neglecta (Lowenstein \& Roberts 1951; Fay et al. 1974; Corwin 1981). The first mechanism, the so-called otolithic channel, arises because of a difference in the density of the otoconial mass compared to the rest of the shark's body. A shark exposed to a sound wave will move in concert with the surrounding water because its body has a similar density (and the shark is small relative to the wavelength of the sound wave) but the more dense otoconial mass will accelerate more slowly than the rest of the shark (Hanson et al. 1990; Hunt 1992; Bretschneider et al. 2001). This inertial lag will be transmitted to the macula via the otolithic membrane and cause the hair bundles to bend (Fay \& Popper 1974). The second-and largely unproven - mechanism, the non-otolithic channel, relies on the conduction of particle motion into the posterior canal duct through a membrane-covered, fluid-filled opening (the fenestra ovalis) located at the base of a depression (the parietal fossa) in the dorsal chondrocranium (Daniel 1934; Lowenstein \& Roberts 1951). Sound waves, particularly those coming from above and in front of the shark, would 
be transmitted to the endolymph within the posterior dorsal canal and cause local displacements of the cupula of the macula neglecta (Fay et al. 1974; Corwin 1977).

Hearing abilities are typically defined in terms of frequency range, threshold detection level (i.e., sensitivity) and directionality. Sharks are able to hear sounds up to about $1000 \mathrm{~Hz}$ and are most sensitive to frequencies below about $100 \mathrm{~Hz}$ (Nelson 1967; Popper \& Fay 1977; Casper \& Mann 2006, 2007a,b, 2009). In an open-water measurement of hearing thresholds in the Atlantic sharpnose shark (Rhizoprionodon terraenovae Richardson, 1836), the highest sensitivity to particle motion was recorded at $20 \mathrm{~Hz}$, which was the lowest frequency tested (Casper \& Mann 2009). As a group, sharks appear to be less sensitive to sound at all frequencies compared to teleosts fishes, either due to the lack of any pressure-to-displacement transduction mechanism (e.g., swim bladder, Weberian ossicles) or because their gelatinous otoconial masses are less dense than the solid otoliths of bony fishes and, therefore, less sensitive to linear motion and acceleration (Casper \& Mann 2007a). Sharks are able to locate a sound source with considerable accuracy (Nelson 1967). However, while it is known that some sharks have omnidirectional hearing (Casper \& Mann 2007b), the neural mechanisms by which sharks locate sound sources remain to be determined (Gardiner et al. 2012).

\section{Lateral line}

Like the inner ear, the lateral line is a mechanosensory structure capable of detecting particle motion and, therefore, may respond to mechanical disturbances produced by both auditory and nonauditory hydrodynamic stimuli (Parker 1904; Dijkgraaf 1963). In addition to low frequency sounds, the lateral line is used to detect the vibrations given off by prey, predators, and conspecifics moving through the water, as well as the direction and velocity of water currents (Boord \& Campbell 1977; Montgomery et al. 1995). Although the stimulus characteristics and frequency response of the lateral line system overlap with those of the auditory system, the lateral line is a short-distance sensory system that responds to low frequency water movements occurring within a few body lengths of the animal (Kalmijn 1989).

The end organs of the lateral line (neuromasts) closely resemble the vestibular and auditory receptors of the inner ear (Hama \& Yamada 1977; Blaxter 1987). Each neuromast contains 
populations of sensory hair cells with differing directional sensitivities determined by the orientation of the stereocilia and kinocilia on their apical surface (Maruska 2001). The hair bundles are embedded within a gelatinous cupula that is displaced relative to the underlying sensory epithelium by movement of the surrounding fluid (viscous drag) and causes bending of the hair cells (Tester \& Kendall 1968; Maruska 2001).

Neuromasts are located in sub-epidermal canals or superficially in grooves or pits between modified denticles (Johnson 1917; Tester \& Nelson 1967; Peach \& Marshall 2009; Theiss et al. 2012a). There are two types of canal system in sharks, one that has numerous pores connecting the canals to the surface of the skin via short tubules, and one that lacks pores and is sealed from the external environment (Maruska 2001; Theiss et al. 2012a). The non-pored canals do not respond to external hydrodynamic stimuli directly but instead respond to movement of fluid within the canals created by displacement of the skin (Maruska \& Tricas 2004). Neuromasts in the non-pored canals are highly sensitive to low frequency $(<10 \mathrm{~Hz})$ displacements and are thought to function as tactile receptors during foraging and feeding behaviors because the non-pored canals are located close to the mouth (Maruska \& Tricas 2004).

The pored canals of the shark lateral line system more closely resemble those of teleost fishes, and the neuromasts lining the canal lumen function as accelerometers that detect the pressure difference between adjacent pores (Denton \& Gray 1983; Blaxter 1987). All canal neuromasts are low-frequency (1-200 Hz) receptors (Dijkgraaf 1963) and in elasmobranchs have greatest sensitivity in the range of $20-30 \mathrm{~Hz}$ (Maruska \& Tricas 2004). Although there is as yet little direct evidence, the pored canal system in sharks is likely to mediate similar behavioral functions (predator avoidance, prey detection, hydrodynamic imaging) to those in the closely related rays and also teleost fishes, especially in relation to prey detection (Montgomery et al. 1995; Jordan et al. 2009a).

Superficial neuromasts (pit organs) are distributed predominantly over the dorso-lateral surfaces of the head and trunk with additional clusters around the spiracles, anterior to the gills, and ventral to the mouth (Tester \& Kendall 1967; Tester \& Nelson 1967; Peach \& Marshall 2009). The cupula of the pit organ neuromast is exposed to water flow in the external environment to a greater or lesser degree depending on interspecific variations in the shape of the pit within which it is located 
and the morphology and coverage provided by the modified denticles that surround them (Peach \& Marshall 2000).

The role of pit organs in shark behavior is unclear, but they may subserve a similar function to the superficial neuromasts of teleosts fishes in detecting the velocity of water flowing over the body (Montgomery et al. 1997) and may be involved in orientation toward water currents (rheotaxis) (Peach 2001). Rheotaxis is thought to be used by many pelagic species of shark for locating and approaching prey and may be essential for orienting to food sources and following odor plumes (Peach 2003; Gardiner \& Atema 2007).

Comparative studies of the lateral line system of sharks reveals marked interspecific variations in the distribution and morphology of both the canals (position, length, branching pattern, number of pores) and the pit organs (number, position) that reflect both phylogenetic inertia and ecological adaptation (Maruska 2001; Peach \& Rouse 2004; Peach \& Marshall 2009; Theiss et al. 2012a). Thus, it is likely that there are also interspecific differences in the sensitivity, directional resolution, and behavioral functions of the lateral line, although much work remains to be done in this regard (Gardiner et al. 2012).

\section{Chemoreception}

Olfaction (smell), gustation (taste) and the common chemical sense collectively comprise the chemosensory system in sharks. Olfaction is associated with functions such as intraspecific social interactions, communication, reproduction and the detection of food. Gustation is primarily involved with feeding and incorporates the use of taste buds to orally process and evaluate the palatability of food through direct contact, eventually leading to a decision to either swallow or reject it.

Examples of stimuli thought to elicit a neurological response in the olfactory system of sharks include the odors of prey, conspecifics (e.g., reproductive partners), predators, and specific habitats. The propagation of these chemoreceptive signals through the environment and the extent to which they are encountered by a given species of shark will depend upon the swimming mode/speed of the shark, water movements and odor concentration (Parker \& Sheldon 1913; Parker 1914; Johnsen \& Teeter 1985). The sensitivity of the shark olfactory system is impressive: using electro-olfactography 
(EOG), response thresholds have been found to lie in the sub-nanomolar range for both alanine $\left(9.2 \times 10^{-11} \mathrm{M}\right)$ and cysteine $\left(8.4 \times 10^{-10} \mathrm{M}\right)$ and in the micromolar range for proline and serine in the scalloped hammerhead shark (Sphyrna lewini Griffith \& Smith, 1834) (Hodgson \& Mathewson 1978; Zeiske et al. 1986; Tricas et al. 2009).

The detection of water-borne olfactory cues takes place in the paired olfactory cavities. The nares open onto an olfactory rosette consisting of numerous parallel stacks of lamellae that provide a large surface area of highly sensitive olfactory epithelium (Tester 1963). Interspecific differences in the placement, size, and entrance shape of the nares, the orientation of the rosette within the olfactory cavity, and the number and shape of the lamellae, likely affect the hydrodynamics of water flow over the olfactory epithelium and, therefore, olfactory sensitivity (Tester 1963; Schluessel et al. 2008; Rygg et al. 2013). Bentho-pelagic sharks and rays possess significantly more olfactory lamellae and a larger sensory epithelial surface area than benthic species (Schluessel et al. 2008; Theiss et al. 2009). However, when species with a greater lamellar surface area were analyzed using EOG, there was no correlation with olfactory threshold, which was relatively similar across all species tested, suggesting that the density of olfactory receptor neurons may show interspecific variation (Meredith \& Kajiura 2010). At present, there are no data on the number or density of olfactory receptors or the level of convergence of the olfactory signals at either the level of the olfactory bulb or the telencephalon in any species of cartilaginous fish.

The relative size of the olfactory bulbs is widely used as a neuroanatomical proxy for olfactory capability in vertebrates, including sharks (Lisney et al. 2007). The largest olfactory bulbs are found in pelagic coastal/oceanic sharks, particularly migratory species such as the great white shark and tiger shark (Yopak et al. 2013), which suggests that olfaction may also play a critical role in shortand/or long-distance navigation. In contrast, the majority of reef-associated species possess the smallest olfactory bulbs, suggesting reliance on other senses such as vision or electroreception (Hart et al. 2006; Collin 2012; Kempster et al. 2012; Lisney et al. 2012; Yopak et al. 2013).

Interestingly, the olfactory bulbs of the lemon shark (Negaprion brevirostris Poey, 1868), the bonnethead shark (Sphyrna tiburo Linnaeus, 1758), and R. terraenovae are divided into two distinct hemibulbs or a series of connected swellings (Northcutt 1978). In a recent study by Meredith et al. 
(2013), the olfactory bulbs were shown to receive somatotopic input from the olfactory receptor neurons (both microvillous and crypt type), making elasmobranchs unique amongst vertebrates for whom the input to the olfactory bulb is typically chemotopic. The high sensitivity to amino acids observed in sharks appears to be mediated by the microvillous type of olfactory receptor neurons (as in teleosts, Sato \& Suzuki 2001; Lipschitz \& Michel 2002), although the crypt type are also thought to be involved (Hansen et al. 2004; Vielma et al. 2008). However, despite the detection of bile salts being restricted to the ciliated olfactory receptor neurons in teleost fishes (which have not thus far been identified in elasmobranchs, Theisen et al. 1986; Eisthen 2004; Schluessel et al. 2008), Meredith et al. (2012) confirm electrophysiological sensitivity to bile salts in S. tiburo, emphasizing that there may be a number of olfactory receptor types still to be characterized in sharks.

Like olfaction, taste plays an important role in feeding, but our understanding of the mechanism and function of taste in aquatic vertebrates is still rudimentary and even less is known in sharks (Atkinson \& Collin 2010). In sharks, taste buds occur within papillae covering the oral and pharyngeal epithelium of the mouth, basihyal ('tongue') and gill arches, with a morphology that appears comparable to the taste buds of teleost fishes, i.e., divided into Types I, II and III (Reutter $e t$ al. 1974). Papillae of various sizes project from the epithelium and are dispersed over the oropharyngeal cavity, gill bars, and oral valves, which suggests that biting and manipulation of prey with the jaws is important for taste assessment. Taste buds in sharks appear more numerous in benthic species and are quite scarce in pelagic species. This suggests that taste bud distribution varies according to the feeding mechanism(s) adopted, i.e., pelagic species feeding predominately on larger and more active organisms bite their prey (where the area around the jaws is more efficient for tasting) and benthic species use suction to consume soft bodied organisms (where tastebuds are found evenly distributed throughout the oral and pharyngeal cavities) (Atkinson \& Collin 2010). Oral denticles lining the oral cavity in sharks are thought to provide a form of protection against abrasion during food consumption to increase friction and grip on prey items as they are manipulated within the mouth, and may control the density of taste buds (Atkinson \& Collin 2012).

Elasmobranchs appear to have relatively low densities of taste buds relative to teleost fishes. In a study of 11 species of elasmobranchs, the lowest density recorded was 4 taste buds per $\mathrm{cm}^{2}$ in the 
oral cavity of the spotted wobbegong shark (Orectolobus maculatus Bonnaterre, 1788) and the greatest was 159 taste buds per $\mathrm{cm}^{2}$ in the pharynx of the eastern fiddler ray (Trygonorrhina fasciata Müller \& Henle, 1841), compared to $800+$ taste buds per $\mathrm{cm}^{2}$ in teleosts (C Atkinson \& SP Collin 2011, unpublished data). Having more papillae, however, does not necessarily equate to a greater gustatory sensitivity as the percentage area of the oropharyngeal cavity covered by papillae was lowest $(0.9 \%)$ in the sharptooth lemon shark (Negaprion acutidens Rüppell, 1837), and highest (2.9\%) in the blue-spotted mask ray (Neotrygon kuhlii Müller \& Henle, 1841) (C Atkinson \& SP Collin 2011, unpublished data). Benthic sharks possess between 1,350 and 2,000 taste papillae; more pelagic species have between 9,250 and 11,900 taste papillae (C Atkinson \& SP Collin 2011, unpublished data).

Solitary chemosensory cells also populate the taste papillae of sharks. These receptors do not appear to aggregate in a bundle or bud, and it is unclear whether this type of gustatory organ is independently innervated (Fahrenholz 1915; Whitear \& Moate 1994). The innervation of the axonless sensory cells of the taste buds in sharks is also not well understood (Finger 1997; Reutter et al. 2000; Finger 2007). When taste substances stimulate these cells in teleost fishes, information is transmitted to the central nervous system via the cranial nerves VII (facial nerve), IX (glossopharyngeal nerve) and X (vagal nerve) (Reutter et al. 2000). In teleosts, the facial nerve supplies the external taste buds on the barbs and lips, fins and body surface, and oral taste buds of the rostral palate, whereas the vagal nerve innervates most of the orobranchial taste buds; the glossopharyngeal nerve plays a minor role in gustatory supply to the oral cavity (Finger 1988; Laverack 1988; Reutter 1992; Kasumyan \& Døving 2003). Future research is needed to investigate the gustatory input to the CNS via these three cranial nerves, especially in light of the fact that no taste papillae have been identified over the external surface of the skin in sharks.

\section{Electroreception}

Sharks have specialized receptors that enable them to detect weak electrical potentials generated by other animals and inanimate objects (Murray 1962; Kalmijn 1982). Sharks use their electric sense primarily to locate and capture prey (Kalmijn 1971; Tricas 1982) and avoid predators 
(Peters \& Evers 1985; Kempster et al. 2013b). They may also be able to detect the weak electrical fields induced in the surrounding water currents or their own bodies as they move through the earth's magnetic field and use this information for orientation/navigation (Kalmijn 1978; Paulin 1995).

Shark electroreceptors (ampullae of Lorenzini) are of the ampullary type (Andres \& von Düring 1988) and develop from lateral line placodes (Gillis et al. 2012). Each ampulla comprises an opening (pore) at the surface of the skin that is connected by a narrow ( $\sim 1 \mathrm{~mm}$ diameter) canal to a chamber (ampullary bulb) located deep within the dermis (Peabody 1897). In most species, the ampullary bulbs are grouped into three subdermal clusters and canals of varying lengths (ranging from $<1$ to $>20 \mathrm{~cm}$ in marine species) radiate out from these clusters to pores distributed across the dorsal and ventral surface of the head (Fishelson \& Baranes 1998; Tricas 2001). Interspecific variations in ampullae/pore abundance, pore location, canal length and orientation reflect ecological adaptations (e.g., habitat, feeding mode) and phylogeny (Raschi et al. 2001; Tricas 2001; Kempster et al. 2012). The morphology of the electrosensory system is sexually dimorphic in some elasmobranchs, implying a differential usage of electroreception by the sexes in reproductive and/or other behaviors (Crooks \& Waring 2013; Kempster et al. 2013a).

Each ampullary bulb comprises several bulbous pouches (alveoli) lined with a sensory epithelium consisting of receptor and support cells (Fishelson \& Baranes 1998; Theiss et al. 2011). The lumen of the ampullary bulb and canal are filled with a conductive mucopolysaccharide hydrogel that provides an electrical connection with the external pore opening and subtly alters the electrical properties of the canal (Murray \& Potts 1961; Doyle 1967; Brown et al. 2005). Tight junctions (zonulae occludens) between the cells lining the lumen of the canal and ampullary bulb form a highresistance barrier that ensures current flows only across the receptor cell membrane and does not leak out of the canal (Clusin \& Bennett 1977). The receptor cells amplify the potential difference between their apical surface inside the lumen and their basal surface outside the lumen (Lu \& Fishman 1994). The clustering of the ampullary bulbs means that the receptor cells of different ampullae share an identical 'reference' potential on their basal surface to which the voltage developed along each canal is compared (Tricas 2001). 
Ampullary receptor cells synapse with primary electrosensory afferents that travel to the brain via the anterior lateral line nerve (Bodznick \& Northcutt 1980). Afferent nerve fibers exhibit a steady discharge of action potentials in the absence of electrical stimulation; the rate of discharge increases or decreases depending on whether the apical surface of the receptor is more negative or more positive than the basal surface, respectively (Murray 1962). Behaviorally, sharks are attracted most strongly to direct current (d.c.) electric fields, but the receptors themselves are low frequency, alternating current (a.c.) detectors that respond optimally to fluctuating fields between $0.1-10 \mathrm{~Hz}$, with peak sensitivity at around $1 \mathrm{~Hz}$ (Peters \& Evers 1985). To detect a steady d.c. voltage, the shark must be moving relative to the voltage source (Kalmijn 1978).

Sharks are capable of responding to voltage gradients $\leq 5 \mathrm{nV} \mathrm{cm}^{-1}$ (Kalmijn 1982; Johnson et al. 1984; Kajiura \& Holland 2002), which allows them to detect the localized biopotentials emitted by prey $(1-500 \mu \mathrm{V})$ at distances of up to $0.5 \mathrm{~m}$ (Kalmijn 1972; Haine et al. 2001) and uniform inductive fields $\left(50-500 \mathrm{nV} \mathrm{cm}^{-1}\right)$ generated by ocean currents (Kalmijn 1971). The downside of such an exquisitely sensitive sensory system is that it is easily saturated by intense transient stimulation. In rays, which have a similar threshold sensitivity of $\leq 1 \mathrm{nV} \mathrm{cm}^{-1}$ (Jordan et al. 2009b), the maximal firing rate of an electrosensory afferent nerve is reached when the voltage across the receptor's apical membrane is about $100 \mu \mathrm{V}$ (Lu \& Fishman 1994). Assuming a canal length of $10 \mathrm{~cm}$, this voltage would be achieved in a uniform field with a voltage gradient of $10 \mu \mathrm{V} \mathrm{cm}^{-1}$, provided the shark was oriented such that the long axis of the canal was parallel to the direction of the field gradient. Interestingly, Kalmijn (1971) noted that small spotted catsharks (Scyliorhinus canicula) exhibited strong escape responses when they encountered a d.c. voltage gradient of $1-10 \mu \mathrm{V} \mathrm{cm}^{-1}$. These findings have obvious implications for the development of electrical shark repellent devices.

\section{SHARK REPELLENTS AND THEIR EFFECTIVENESS}

Shark attacks or shark depredation may be prevented either by making an object aversive (directly through its appearance or indirectly through something it discharges) or by altering its stimulus qualities to make it more difficult to detect (i.e., camouflage). Of the various attempts to develop shark repellents, by far the majority have relied on making an object aversive, perhaps 
because making an object 'invisible' to all of the sharks various senses at once is quite a challenge. The following section provides a summary of the major breakthroughs in shark repellent research over the last 70 years. Although excellent reviews of the earlier (pre-1980) work are already available (e.g., Nelson 1983), a synthesis is presented here along with the latest research, as many of the problems encountered in the past are entirely relevant to today's efforts to improve on existing repellent technologies and develop new devices.

\section{Chemical repellents}

The first concerted effort to identify an effective shark repellent began during WWII in an attempt to find a way to prevent sharks from attacking military personnel who found themselves adrift in the ocean. Preliminary experiments to identify substances that would disrupt shark feeding behavior were conducted in 1942 using smooth dogfish (Mustelus canis Mitchill, 1815) held in aquaria at the Woods Hole Oceanographic Institution (Burden 1945; Springer 1955). Numerous chemical agents were tried unsuccessfully, including known fish poisons such a rotenone, chlorine, metallic poisons, irritants, ink clouds, and other unspecified "chemical stenches and poison gas generators" (Springer 1955). In many cases, the sharks readily ate bait containing toxins that subsequently killed them.

Feeding responses of $M$. canis were suppressed using maleic acid and malic acid. However, the best repellents were found to be rotten shark flesh, which had been allowed to stand for 4-6 days at $20^{\circ}$, and low concentrations of copper salts, notably copper sulfate (Springer 1955; Brown 1973). Further experimentation revealed that the primary repellent agent in rotting shark flesh was ammonium acetate. The finding that both acetate ions and copper salts were repellent led to the selection of copper acetate for further trials (Hodgson \& Mathewson 1978). Subsequent open-water testing appeared to confirm the efficacy of copper acetate when it was shown to reduce the number of strikes on set baits protected by the repellent compared to control baits without the repellent (Burden 1945). However, under conditions described as a 'feeding frenzy' triggered by discarding large amounts of waste fish from a shrimping boat, copper acetate was found to be considerably less effective in repelling sharks. 
In 1943, the work on shark repellents was taken over by the US Naval Research Laboratory. It was found that a modified nigrosine-type dye (Calco WBSR) was highly effective in suppressing feeding behavior in a variety of feeding situations. Although the dye was originally intended to disguise a swimmer much like a cephalopod releases a cloud of ink to escape a predator, it was found to be effective during both day and night, suggesting a chemical, as well as visual, mode of action (Fogelberg 1944). On their own, both copper acetate and Calco WBSR were capable of deterring a variety of shark species, including blacknose sharks (Carcharhinus acronotus Poey, 1860), C. limbatus, and other carcharhinid and sphyrnid shark species. The combination of Calco WBSR dye (80\%) with copper acetate (20\%) was shown to have a synergistic effect in repelling sharks, even during mass feeding events, and was rapidly developed into a cake formulation bound together by water-soluble wax (the 'Shark-Chaser') that could be attached to a life jacket and exposed to the water by a floating survivor when required (Fogelberg 1944; Burden 1945).

In 1944, at the behest of the Royal Australian Air Force and the Royal Australian Navy, independent testing of copper acetate-based repellents was conducted in Shark Bay, Western Australia (Whitley \& Payne 1947). Copper acetate, in combination with another basic dye (Methic Leather Black D.G.) that on its own was apparently only a weak deterrent, was shown to reduce shark catch on baited hooks by $\sim 95 \%$ compared to controls lacking the deterrent. Although it was not possible to observe the species of shark that were repelled, especially as most of the catch was taken at night, the species caught on the control lines were predominantly tiger (Galeocerdo cuvier Péron \& Lesueur, 1822), sandbar (Carcharhinus plumbeus Nardo, 1827), spinner (Carcharhinus brevipinna Müller \& Henle, 1839), and nervous (Carcharhinus cautus Whitley, 1945) sharks.

After the war, further work on shark repellents was conducted as part of an extensive research program on basic and applied shark biology led by Perry Gilbert and funded largely by the US Office of Naval Research. Between 1958 and 1968 at the Lerner Marine Laboratory at Bimini in the Bahamas, over a hundred different chemical agents were tested on large sharks, including a variety of metallic salts, amino acids, nicotine, human sweat and urine (Hodgson \& Mathewson 1978). In contrast to earlier results, copper acetate was shown to be ineffective as a feeding inhibitor or repellent for C.plumbeus, G. cuvier, C. leucas, N. brevirostris, dusky (Carcharhinus obscurus 
Lesueur, 1818), blacktip reef (Carcharhinus melanopterus Quoy \& Gaimard, 1824), and nurse (Ginglymostoma cirratum Bonnaterre, 1788) sharks. The only compound shown to have a significant repellent effect on $N$. brevirostris was the nigrosine dye from the Shark Chaser (Gilbert 1970). Because of these conflicting and disappointing results, research on chemical shark repellents was largely abandoned.

However, interest in chemical shark repellents was renewed following the discovery of naturally occurring ichthyotoxins contained in a milky secretion released from paired glands located at the base of the dorsal and anal fin rays of soleoid fishes of the genus Pardachirus (Clark \& Chao 1973; Clark \& George 1979). The secretion from the Red Sea Moses sole (Pardachirus marmoratus Lacepède, 1802) was found to be highly toxic to small teleost fishes and could repel whitetip reef sharks (Triaendon obesus Rüppell, 1837) and other predatory fishes for at least 17 hours (Clark 1974; Clark 1983; Zlotkin \& Gruber 1984). A protein with neurotoxic and haemolytic activity (pardaxin) was isolated from the secretion of P. marmoratus (Primor \& Zlotkin 1975; Primor et al. 1978) and shown to cause mouth paralysis and acute irritation of the gills and pharyngeal cavity of the piked dogfish (Squalus acanthias Linnaeus, 1758) (Primor 1985). Three virtually identical isoforms of pardaxin-like protein were also isolated from the defence secretion of the congener peacock sole (Pardachirus pavoninus Lacepède, 1802) and were shown to trigger escape responses when injected into the mouths of T. obesus (Thompson et al. 1986).

In addition to pardaxin proteins, the secretions of both P. marmoratus and P. pavoninus were subsequently found to contain a number of ichthyotoxic steroidal aminoglycosides (saponins) called mosesins (M1-M5) and pavoninins (P1-P6), respectively (Tachibana et al. 1984; Tachibana et al. 1985; Tachibana \& Gruber 1988). Both mosesins and pavoninins were shown to inhibit feeding behavior in $N$. brevirostris and/or rouse them from a state of tonic immobility when introduced into the buccal or olfactory cavities, indicating significant repellent activity. A similar steroidal saponin, holothurin, produced by the sea cucumber (Actinopyga agassizi Selenka, 1867) as an anti-predator defence, is also known to be toxic and repellent to N. brevirostris, G. cirratum, and S. tiburo (Sobotka 1965; Hodgson et al. 1967). Although promising as a shark repellent, the Pardachirus secretion is thermolabile and loses much of its ichthyotoxic activity when freeze-dried for long term storage 
(Primor \& Zlotkin 1975; Clark \& George 1979). Moreover, while it is possible to synthesise pardaxin and pavoninins artificially (Shai et al. 1988; Williams et al. 2002), at the time of their discovery they could not be produced in sufficient quantities for widespread use (Sisneros \& Nelson 2001).

However, subsequent studies on the chemical structure and pharmacological action of pardaxin and pavoninin, in particular their ability to disrupt the integrity of lipid membranes (Primor 1983; Primor et al. 1984), led to the identification of some alternative repellent substances. Pardaxins and pavoninins exhibit strong surfactant activity (Thompson et al. 1986; Williams et al. 2002), which is a common feature of other toxic defensive skin secretions (Hashimoto 1979) and was thought to be responsible for both the toxic action and the repellent activity of pardaxin in particular (Zlotkin \& Gruber 1984). To test this hypothesis, Zlotkin and Gruber (1984) screened a range of natural and commercially available surfactant chemicals for their ability to disrupt the feeding behavior of captive $N$. brevirostris or rouse them from a state of tonic immobility. They identified two anionic detergents as potent shark repellents: sodium dodecyl sulfate (SDS) and lithium dodecyl sulfate (LDS).

Further laboratory studies with horn sharks (Heterodontus francisci Girard, 1855), swell sharks (Cephaloscyllium ventriosum Garman, 1880), and leopard sharks (Triakis semifasciata Girard, 1855) confirmed that SDS was effective at triggering aversive reactions (Smith 1991; Sisneros \& Nelson 2001). The effective concentration of SDS (at which half of the sharks demonstrated strong avoidance behaviors) was in the range of $83-175 \mathrm{ppm}$, although subtle reactions were evident at concentrations as low as $36 \mathrm{ppm}$. Importantly, the sharks did not habituate to the chemical when exposed to it repeatedly. In contrast, copper acetate at concentrations as high as $2240 \mathrm{ppm}$ did not elicit any discernible responses (Smith 1991). Field trials with bait-attracted blue sharks P. glauca and white sharks (Carcharodon carcharias Linnaeus, 1758) also demonstrated that direct delivery of a $10 \%$ solution of SDS in seawater into the mouth of a feeding shark (compared to a seawater-only control) resulted in head shaking, mouth gaping, and permanent departure from the test site (Nelson \& Strong 1996). While the promise of a reliable, readily available, and comparatively cheap chemical repellent like SDS, which is also relatively non-toxic to humans, is appealing, the release of large amounts of any artificial chemicals into the marine environment is undesirable. Moreover, the concentration at which SDS is effective in repelling sharks is still considerably higher than that which is considered 
practical for creating a sustained, non-directional, surrounding-cloud type chemical repellent (10$100 \mathrm{ppb}$ ), based on the fact that even highly toxic or repellent chemicals will be diluted rapidly in open water (Baldridge 1990).

Recent attempts to identify more effective chemical shark repellents have focussed on compounds (semiochemicals) that are of biological relevance to sharks rather than merely an irritant to their senses. Rasmussen and Schmidt (1992) hypothesised that juvenile N. brevirostris would inherently recognize chemicals (kairomones) given off by their natural predator, the American crocodile (Crocodylus acutus Cuvier, 1807). They demonstrated that water samples taken from holding tanks containing captive C. acutus could trigger the reversal of tonic immobility in N. brevirostris, whereas water samples taken from holding tanks of American alligator (Alligator mississippiensis Daudin, 1802), which are not a major predator of $N$. brevirostris, had no visible effect. A chemical analysis of $C$. acutus water extracts identified two candidate molecules that are probably excreted in crocodile faeces: 2-ethyl-3-methylsuccinimide (3-ethyl-4-methylpyrrolidine-2,5dione) and 2-ethyl-3-methylmaleimide (3-ethyl-4-methyl-1H-pyrrole-2,5-dione). Even at very low concentrations $\left(10^{-7}-10^{-9} \mathrm{M}\right.$; equivalent to 0.14 to $14 \mathrm{ppb}$ given relative molar masses of 141.2 and 139.2, respectively) these compounds were able to reverse tonic immobility in N. brevirostris in 60 $80 \%$ of trials (Rasmussen \& Schmidt 1992). Although it is difficult to be certain that the state of tonic immobility was disturbed through an avoidance response rather than a feeding response to these compounds, the fact that sharks are able to detect the chemical signatures of potential predators indicates a promising avenue for the development of semiochemical-based shark repellents. For example, there are reports (Hainke 2010) of predation on bull sharks (C. leucas) by saltwater crocodiles (Crocodylus porosus Schneider, 1801), which share large areas of coastal and estuarine habitat in northern Australia. It may be possible to find similar semiochemicals that are effective in repelling C. leucas, a species responsible for both fatal and non-fatal bites on humans (Baldridge 1974).

Taking inspiration from the earlier work of Springer (1955), who showed that rotting shark flesh was a potent repellent, Stroud et al. (2013) have revisited the idea of 'necromones': semiochemicals given off by dead or decaying animals that function to alert other animals to the 
presence of potential predators (Yao et al. 2009). A commercially available, aerosolized preparation (Repel Sharks, LLC) of putrefied shark tissue extract was shown to be capable of dispersing competitively feeding aggregations of Caribbean reef sharks (Carcharhinus perezi Poey, 1876) and C. acronotus for approximately 10 minutes, even when delivered at relatively low concentrations. Some sharks (all C. perezi) returned after 10 minutes, but they appeared to be less interested in feeding. A chemical analysis of the shark extract revealed high concentrations of acetic acid in addition to a plethora of amino acids, short chain and fatty carboxylic acids, amines, and short chain lipid oxidation products (Stroud et al. 2013). Acetate ions have already been shown to repel sharks (see above), and it remains to be seen whether any of the other constituents are also repellent. A similar approach has been proposed for use in the Great Lakes to control invasive sea lampreys (Petromyzon marinus Linnaeus, 1758), which show avoidance behaviors when exposed to chemicals released by dead and decaying conspecifics (Imre et al. 2010; Pietrzakowski et al. 2013). The remaining challenges with all of these chemical repellents are to isolate compounds that are both nontoxic and effective at very low concentrations, such that rapid dispersion by water currents under reallife deployment conditions does not negate their repellent effect.

\section{Electrical and magnetic repellents}

A natural aversion by sharks to electrical fields was first recognised in 1935 when it was shown that blindfolded S. canicula demonstrated oriented escape reactions to a rusty steel wire brought close to the head. The galvanic currents generated at the surface of the wire were sufficiently large to be detected by the shark's highly sensitive electroreceptive system (Kalmijn 1971). Although subsequent research demonstrated that sharks are also attracted to certain electrical fields (see above), it was quickly recognized that the use of electric stimuli that differ in frequency or strength from those characteristic of prey were clearly a potential mechanism by which sharks could be repelled.

\section{Active electrical repellents}

There have been various attempts to develop 'active' electrical shark repellent devices that utilise a power source to generate the electric field. One of the first successful devices, the original 'Shark Shield' developed by Electromagnetic Industries, was available in two configurations: one to 
be worn by SCUBA divers, and one for use to prevent sharks from damaging the cod-ends of shrimptrawl nets (Nelson 1983). The device consisted of a rechargeable battery-powered, capacitordischarge unit connected to two or four woven-metal electrodes, which delivered a $120 \mathrm{~V}$ square wave pulse of $60 \mathrm{~ms}$ duration at a frequency of $1-2 \mathrm{~Hz}$ (Hurley et al. 1987). In aquarium tests, the Shark Shield was shown to be effective in repelling four different species of captive adult sharks known to be dangerous to humans, including N. brevirostris (Gilbert \& Gilbert 1973). In field trials with tuna purse seine nets, the Shark Shield kept sharks at least $3 \mathrm{~m}$ from the electrodes (Nelson 1983). However, in many cases, the repellent effect of such electrical devices was highly speciesspecific. For example, Gilbert (1970) tested four different types of electrical repellent on captive sharks between 1958-1969 and showed that G. cuvier were attracted to electrical pulses that quickly repelled N. brevirostris. Similarly, studies aimed at preventing sharks from biting submarine telecommunications cables found that $N$. brevirostris, but not $G$. cirratum, were repelled by a moving dipole generating a d.c. current of 1.6 A (Hurley et al. 1987).

Research by the Kwazulu-Natal Sharks Board (South Africa) into the use of electrical fields to repel sharks led to the development of the SharkPOD ${ }^{\mathrm{TM}}$ (Protective Oceanic Device) for use by SCUBA divers. Similar to earlier devices, the SharkPOD consisted of an electrical waveform generator and two widely separated electrodes (one located on the SCUBA tank and the other located on the fin) that created an electrical field surrounding the diver (KZNSB 2011). Early testing showed that the SharkPOD was effective in eliciting avoidance behaviors from C. leucas, C. carcharias, G. cuvier, and grey nurse sharks C. taurus (Taylor 1998) and significantly reduced the frequency with which $C$. carcharias attacked baits attached to an activated device compared to controls when the device was switched off (Smit \& Peddemors 2003). Commercial distribution of the SharkPOD commenced in 1995/6 and ceased in 2001, but the patented electrical waveform technology was subsequently licensed to an Australian company (SeaChange Technology Pty. Ltd., now SharkShield Pty. Ltd.), which developed new versions of the electrical repellent device for use by divers, surfers, and kayakers. The Freedom $7^{\mathrm{TM}}$ and Scuba $7^{\mathrm{TM}}$ devices are widely used by recreational, commercial, and professional divers. A military version with reduced field strength is also available (Defense 2013). The Freedom $7^{\mathrm{TM}}$ device produces exponentially decaying pulses lasting approximately $1.2 \mathrm{~ms}$ 
with peak amplitude of $105 \mathrm{~V}$ at a frequency of $\sim 1.7 \mathrm{~Hz}$ (Huveneers et al. 2013). In field tests with wild $C$. carcharias, the device was shown to increase the time taken to consume static tuna baits located within 1-3 $\mathrm{m}$ of the electric field source (i.e., within the reported protective envelope), but overall did not reduce the number of baits attacked. In contrast, the device significantly and dramatically reduced the number of breaches and surface interactions against seal-shaped decoys towed along the surface of the water (Huveneers et al. 2013). Other devices with similar modes of operation are either in development or commercially available, including the Electronic Shark Defense System (ESDS), although as yet no independent testing appears to have been conducted on this device.

Devices such as the Shark Shield were designed primarily for personal protection against sharks, but one of the challenges now is to explore ways of using electric repellents to reduce shark bycatch and depredation in fisheries, perhaps through miniaturization of electrical devices for deployment on nets or longline gear (Jordan et al. 2013), and for protection of humans over larger spatial scales such as beaches. Previous attempts to provide area-level protection, such as the antishark electrical cable that was deployed in the St. Lucia estuary (employing a pulsed d.c. field of 3$7 \mathrm{~V} \mathrm{~m}^{-1}$ ) and off Margate Beach in South Africa, proved effective at deterring a variety of shark species, including C. leucas (Smith 1974). However, these devices were either too costly to install and maintain or suffered from extensive damage when deployed over sections of exposed reef. Consequently, they were not widely adopted (Gilbert 1970; Cliff \& Dudley 1992). Nevertheless, research into shark repellent cables is ongoing and may prove to be a credible option for protecting beachgoers, especially if the total cost of operation and maintenance can be reduced by modifications to waveform design and/or delivery (Cliff \& Dudley 1992; KZNSB 2011).

\section{Passive electrical repellents - electropositive metals}

Another approach to the design of electrical deterrents is the use of strongly electropositive metals (EPMs), which react vigorously with water when immersed and generate electrical potentials that are thought to overstimulate the sharks' highly sensitive electroreceptors (Rice 2008; Stoner \& Kaimmer 2008). Primarily intended as a mechanism to reduce shark bycatch and catch depredation in 
longline fisheries, without affecting the catch of non-electrosensitive target teleost fishes, EPMs can be formed into shapes that are easily attached to a fishing line or hook. Initial laboratory tests with captive sharks showed that several EPMs (including magnesium and rare-earth lanthanide elements such as cerium, lanthanum, neodymium and praseodymium) were effective in rousing $N$. brevirostris and G. cirratum from a state of tonic immobility (Rice 2008) and in repelling S. acanthias and C. plumbeus from tethered baits (Stoner \& Kaimmer 2008; Brill et al. 2009). However, subsequent testing showed no repellent effect of EPMs on S. tiburo or N. brevirostris (McCutcheon \& Kajiura 2013) and that aversive behavior shown by S. acanthias and M. canis was highly dependent on the duration of food deprivation prior to testing and/or the presence of conspecifics. Hungry sharks ignored the EPM to take the bait, especially when feeding in groups (Tallack \& Mandelman 2009; Jordan et al. 2011).

The results of field trials using fishing gear fitted with EPMs were also mixed, with some studies showing a reduction in the catch rate of/depredation by S. acanthias, C. plumbeus, S. lewini and Galapagos sharks (Carcharhinus galapagensis Snodgrass \& Heller, 1905) (Kaimmer \& Stoner 2008; Wang et al. 2008; Brill et al. 2009; Hutchinson et al. 2012; O'Connell et al. 2013b). Other studies showed no effect on the catch rate of/depredation by S.acanthias, C.plumbeus, C. galapagensis, G. cuvier, P. glauca, shortfin mako (Isurus oxyrinchus Rafinesque, 1810) and pelagic thresher sharks (Alopias pelagicus Nakamura, 1935) (Tallack \& Mandelman 2009; Robbins et al. 2011; Hutchinson et al. 2012; Godin et al. 2013). A number of factors may influence the efficacy of EPMs in repelling sharks, including the type of EPM used, the relative sensitivity of the electrosensory system, shark density and competition, hunger level, and differences in feeding ecology (Godin et al. 2013). Other impediments to large scale adoption of EPM technology by commercial fisheries include the relatively high cost of the rare-earth metals (although magnesium may represent a cheaper alternative), potential toxicity to other marine animals, and the fact that they dissolve rapidly in seawater and, therefore, must be replaced frequently (Brill et al. 2009; McCutcheon \& Kajiura 2013; O'Connell et al. 2013b). The use of EPMs for personal shark deterrent devices is also hampered by the limited effective range $(<85 \mathrm{~cm})$ of the electrical field they generate (McCutcheon \& Kajiura 2013). 
Passive electrical repellents - permanent magnets

Possible alternatives to EPM repellents are permanent magnets, which are thought to act on the electrosensory system indirectly through electromagnetic induction (O'Connell et al. 2013c), which is the same physical mechanism that is thought to allow sharks to detect the earth's magnetic field (Kalmijn 1978; Kalmijn 1982). Both ceramic (barium-ferrite) and rare-earth type (neodymium-ironboron) magnets have been investigated as possible shark repellents (O'Connell et al. 2013c). Ceramic magnets are comparatively cheap and do not degrade in seawater but are relatively weak (typical residual flux density 2,000-5,000 gauss (G), ASTM 2007) compared to rare-earth magnets. Therefore, larger ceramic magnets are required to provide a given magnetic field strength. Rare-earth magnets contain EPM elements that degrade in seawater and are more expensive than ceramic magnets but are considerably stronger (typically 8,300-14,100 G, MMPA n.d.). Given that the earth's magnetic field ( $\sim .5 \mathrm{G}$ at the surface) is thought to be capable of inducing electrical potentials in ocean currents (50$500 \mathrm{nV} \mathrm{cm}^{-1}$ ) that would be readily detected by the shark's highly sensitive electroreceptors (detection threshold $\leq 5 \mathrm{nV} \mathrm{cm}^{-1}$; see above), strong permanent magnets are probably capable of inducing large potentials that would be quite unlike anything encountered by sharks in their natural habitat.

Sharks are clearly able to detect and respond to strong magnetic fields. Stroud et al. (2005) showed that juvenile $N$. brevirostris, C. limbatus and G. cirratum could be aroused from a state of tonic immobility by magnetic fields of about $50 \mathrm{G}$, generated by moving a $10,000 \mathrm{G}$ rare-earth magnet within 10-20 cm of their head. Rigg et al. (2009) demonstrated that free-swimming captive sharks, including S. lewini, grey reef sharks (Carcharhinus amblyrhynchos) and Australian blacktip sharks (Carcharhinus tilsoni), react to static magnetic fields greater than $25 \mathrm{G}$ at distances of $0.26-$ $0.58 \mathrm{~m}$ by swimming faster or turning away from the source. However, studies investigating the ability of magnets to protect baits from depredation have provided conflicting results. Captive S. acanthias and wild C. galapagensis displayed behaviors suggestive of irritation or aversion when encountering small rare-earth magnets attached to tethered baits, but the presence of the magnetic field (4-1475 G in the case of $C$. galapagensis) did not significantly reduce the overall likelihood of depredation compared to controls (Stoner \& Kaimmer 2008; Robbins et al. 2011). In contrast, O'Connell et al. (2010) showed that G. cirratum avoided bait protected by a C8-grade barium-ferrite 
magnet $(150 \times 100 \times 50 \mathrm{~mm}$; residual flux density $\sim 950 \mathrm{G})$ compared to baits paired with a nonmagnetic clay brick control. Smith and O'Connell (2013) found that S. canicula actively avoided baits protected by an N52-grade neodymium rare-earth magnet $(20 \mathrm{~mm}$ diameter $\times 30 \mathrm{~mm}$ height; residual flux density $\sim 14,000 \mathrm{G}$ ) compared to baits associated with a lead weight control.

Mixed results were also obtained in a dual longline and hook-and-line study (O'Connell et al. 2011b). Shark catch rate on longline gear was not reduced by the presence of strong $(14,800 \mathrm{G})$ neodymium magnets on the hook shaft but was significantly less than controls (bare hooks or hooks with a lead weight on the shaft) when using weaker $(3,850 \mathrm{G}) \mathrm{C} 8$ barium-ferrite magnets (O'Connell et al. 2011b). The repellent effect of the barium-ferrite magnets was also species-specific in that they significantly reduced the catch of C. limbatus, but not of C. plumbeus, N. brevirostris, and other species. Using hook-and-line gear with either a magnet or lead weight control attached directly to the bait rather than the hook, strong neodymium magnets did result in a reduction in the catch of $M$. canis and $R$. terraenovae, but not $S$. canis. In a further example that the repellent efficiency of magnets and other deterrent technologies is highly species-specific, field trials with $C$. carcharias show that tethered baits protected by a strong ceramic magnet were actively avoided and eaten significantly less frequently than baits protected by a non-magnetic clay brick control (O'Connell et al. 2013a).

In an attempt to combine both EPM and magnetic repellent technologies, a so-called SMART $^{\mathrm{TM}}$ (Selective Magnetic and Repellent-Treated) hook has been developed that generates a voltage of up to $1.3 \mathrm{~V}$ when immersed, as well as a magnetic flux of $80 \mathrm{G}$, and has been shown to reduce the catch rate of S. acanthias on longline fishing gear (O'Connell et al. 2013b). The fact that the relatively weaker magnetic fields generated by barium-ferrite magnets and the SMART hooks are more effective in reducing depredation across these studies, rather than stronger fields generated by neodymium magnets, highlights the need to establish a repellent 'strength' that is optimally effective rather than just opting for the maximum that can be generated.

The main impediments for incorporating magnetic repellents into fishing gear is the additional cost and weight of the material and the tendency for magnets to attract one another (or other metal objects) and thus cause entanglement (Rigg et al. 2009). Like EPMs, magnetic repellents only have a 
relatively short effective range because the field strength of a magnetic dipole falls off approximately as the inverse cube of the distance from the source. For example, S. canicula displayed avoidance behaviors only when they encounter flux densities of $\sim 21-2,152 \mathrm{G}$ at a distance of $\sim 2-20 \mathrm{~cm}$ from a powerful rare-earth magnet (Smith \& O'Connell 2013), which highlights the potential importance of the proximity and location of magnets relative to the bait for preventing depredation (Robbins et al. 2011). Thus, a large number of magnets would be required to generate a magnetic repellent with extensive spatial coverage. However, it is possible that arrays of magnets could be deployed around gill nets to form a magnetic barrier that would deter sharks, while allowing target teleost species to reach the net (Jordan et al. 2013). In this respect, it is encouraging that naive $N$. brevirostris have been shown to be reluctant to pass through openings surrounded by strong magnets, although they habituated to the magnets with repeated exposure, and so the repellent effect was short-lived (O'Connell et al. 2011a). Moreover, in a separate experiment using arrays of submerged vertical plastic pipes carrying either magnets or control bricks, the magnets appeared to enhance the ability of the apparent visual 'barrier' (represented by the pipes) to deter $C$. carcharias from passing through the array (O'Connell et al. 2013a). Such findings also show the potential for visual-magnetic barriers to be used to exclude sharks from designated areas, such as beach swimming zones. A trial currently underway near Cape Town, led by C. Matthee of Stellenbosch University, is investigating the use of such a structure (the 'Sharksafe' barrier), as an alternative to traditional shark nets. The Sharksafe barrier relies on the use of strong magnets as well as numerous rigid upright pipes that visually resemble stands of kelp, which $C$. carcharias are thought to avoid entering when in pursuit of prey (Maditla 2013).

\section{Visual repellents}

One of the most effective and technologically simple shark deterrents developed to date is the Shark Screen developed by US Naval Scientist C. Scott Johnson (Tester et al. 1968). Essentially a large, impermeable bag with three inflatable collars around the opening at the top, it is designed such that a person adrift in the water can get into the bag, fill it with water and blow up the collars to keep it afloat. The bag does not provide physical protection against a shark but instead completely conceals 
the occupant visually, contains body odors or effusions (e.g., blood, urine) that might attract sharks, isolates any bio-electrical emissions, and damps water displacements caused by body movements. Tests with captive and wild sharks, including C. milberti, T. obesus, and C. melanopterus, revealed a general reluctance by the sharks to approach the bags. Even when motivated by the presence of food in the water nearby, the sharks largely ignored the bags while feeding (Tester et al. 1968).

The overall reflectivity of the bag had a significant influence on whether or not the sharks would approach it. White and silver bags with high reflectivity tended to attract sharks, whereas blue and black bags of low reflectivity were least attractive (Gilbert 1968; Tester et al. 1968; Gilbert 1970). Subsequent testing with other sea-survival equipment, including lifejackets and a cocoon-like infant flotation device ('IFD') designed for commercial airlines, demonstrated a similar tendency for sharks such as C. leucas, G. cuvier, and C. milberti to ignore objects with low reflectivity. In open water trials, P. glauca and I. oxyrinchus readily attacked child dummies dressed in standard bright yellow lifejackets but ignored dummies dressed in black lifejackets or housed within the black IFD (McFadden \& Johnson 1978).

Sharks either have very poor color vision or are completely color blind (Hart et al. 2011 and see above); thus, the sharks were almost certainly not responding to the color (spectral reflectance) of the yellow life jackets but rather their overall reflectance, or more specifically, their high visual contrast against the background. While devices such as the Shark Screen would no doubt be useful in a survival situation, they are not practical for use by people actively swimming in the water. Nevertheless, the same principles of visual camouflage may apply to swimming apparel such as wetsuits. With this in mind, reflectance spectra that provide minimal visual contrast against the water background for the shark visual system have been calculated (Hart et al. 2012, unpublished data) and used to design 'cryptic' wetsuit patterns that may reduce the risk of shark bite (SAMS 2013). Field testing of the wetsuit prototypes is currently underway to determine whether a camouflaged design is less attractive to sharks than a standard black wetsuit.

Taking a different approach based on his experiences diving in the western Pacific, marine biologist Walter Starck developed a black-and-white banded wetsuit that was intended to mimic the banded poisonous sea snakes that many sharks appeared to avoid eating (Doak 1974; Nelson 1983). 
Whilst $T$. obesus appeared to be unaffected by the banded wetsuit, it was reported to have a repellent effect on C. amblyrhynchos, C. galapagensis, and silvertip sharks (Carcharhinus albimarginatus Rüppell, 1837). Doubt was cast on the effectiveness of the banded suit based on testing performed in the Marshall Islands in the northern Pacific Ocean, but these negative results might have been because the test sites were not inhabited by sea snakes, and local shark populations may not have had the opportunity to learn to avoid them (Nelson 1983). This controversy also serves to highlight the difficulties in assessing repellence when complex multi-sensorial cues are available and the problems inherent in testing shark repellents when sharks must be induced (with food) to interact with them. The repellent effects of some devices may be subtle and provide a useful level of protection against unprovoked bites under normal conditions, but may be significantly reduced when sharks are provoked into feeding, especially when in groups (Gilbert 1962).

The use of visual 'barriers' has already been mentioned in reference to arrays of vertical pipes that resemble kelp stands into which white sharks are thought to be reluctant to swim, especially when combined with strong magnets (see above). Another attempt to generate a visual barrier that would repel sharks was the innovative use of a bubble curtain generated by air escaping from a submerged perforated hose. Initial trials in an aquarium with captive sharks appeared promising, with many large sharks reportedly refusing to swim through the bubbles (McCormick 1963). However, subsequent testing showed that only one of twelve adult captive tiger sharks was in any way repelled by a bubble curtain (Gilbert \& Gilbert 1973). Similar species-specific responses to bubble curtains have been observed in teleost fishes (Sager et al. 1987). While the bubbles may or may not act as a visual repellent for different shark species, there is also the possibility that they can produce hydrodynamic cues that may affect shark behavior through stimulation of the auditory or lateral line systems. Modifications to the technology based on bubble size, air pressure, and/or air flow rate may enhance the repellent effect of what would be a simple and environmentally friendly deterrent device.

Many species of teleost fishes are known to avoid flashing lights. For example, xenon strobes operating at $2-10 \mathrm{~Hz}$ have been used successfully as 'behavioral guidance' tools to keep estuarine fishes away from power station cooling-water intake structures (Sager et al. 1987). These optimal flash frequencies are in close agreement with the flicker rate of maximal contrast sensitivity in a range 
of fishes (5-13 Hz; McFarland \& Loew 1983). A similar approach with flashing lights has been used to keep lions away from domestic livestock on farms surrounding national parks in Africa (Kermeliotis 2013), which further suggests that the very unnatural visual stimulation created by flashing lights may be repellent to a range of animals. No serious attempts appear to have been made to investigate the use of bright flashing lights to repel sharks. This work is currently underway in our laboratory.

Species-specific responses to lights may represent one way in which visual deterrents may be adapted to reduce fisheries bycatch of sharks and even increase the catch of target species (Jordan et al. 2013). Colored electric lights and chemiluminescent 'cyalume' sticks are used in tuna and swordfish longline fisheries as lures to attract target fish to a baited hook. Given some of the key differences in temporal resolution and spectral sensitivity between sharks and teleost fishes, it may be possible to design lures that emit light at a wavelength to which the target fish are more sensitive than are sharks, or at a frequency that is repellent to sharks but attractive to target fishes. For example, the retina of the yellowfin tuna (Thunnus albacores Bonnaterre, 1788) contains single cones, twin cones, and rods that express visual pigments with $\lambda_{\max }$ values at 426,485 , and $483 \mathrm{~nm}$, respectively (Loew et al. 2002), whereas many pelagic sharks appear to have only a single type of cone containing a visual pigment with a $\lambda_{\max }$ value between 532 and $554 \mathrm{~nm}$, in addition to a rod pigment with a $\lambda_{\max }$ value between 500 and $518 \mathrm{~nm}$ (Hart et al. 2011). Thus, the spectral sensitivity of the tuna is almost certainly greater at shorter (blue) wavelengths than the sharks' sensitivity under both scotopic and photopic conditions, and the use of blue light-emitting lures instead of the popular yellow-green ones might help to reduce shark bycatch.

\section{Auditory repellents}

Sharks such as G. cuvier, C. falciformis, and C. leucas are attracted to irregularly pulsed (amplitude modulated), mixed low frequency sounds, especially those in the $20-60 \mathrm{~Hz}$ range that resemble sounds emitted by injured or struggling fish (Nelson \& Gruber 1963; Myrberg et al. 1972). On the other hand, certain sounds can be repellent to sharks. Experiments with captive N. brevirostris and wild C. falciformis demonstrated their rapid withdrawal from a playback of the 'scream' of a 
natural shark predator, the killer whale (Orcinus orca Linnaeus, 1758) (Myrberg et al. 1978; Klimley \& Myrberg 1979). However, there appeared to be no unique quality to the killer whale scream: broadband, low-frequency-biased 'pink noise' of a similar waveband $(500-4,000 \mathrm{~Hz})$ to the scream was even more effective at repelling the sharks. Crucially, most sounds can elicit withdrawal if they start suddenly and/or rapidly increase in loudness, including medium-frequency pure tones and even lowfrequency pulsed sounds that would otherwise attract sharks..

Infrasound $(<20 \mathrm{~Hz})$ has been used as a behavioral guidance tool for salmonids and eels to prevent them from entering hydropower facilities or cooling-water intakes, and may work to repel these fishes because infrasound stimulates the lateral line and mimics the hydrodynamic movements caused by larger, potentially predatory, fishes (Sand et al. 2000). It is unknown whether sharks are also repelled by infrasound, but its use as a repellent is limited by the great size and cost of the transducers required to generate low frequency particle motion that would travel any appreciable distance underwater (A Popper, pers. comm.), and by the potential for disturbance of other marine animals.

Currently, only a single device (Sharkstopper ${ }^{\circledR}$ ) is being marketed as an acoustic repellent for both personal protection (swimmers, SCUBA divers, water craft) and for prevention of shark depredation on fishing gear. Based on specifications obtained from patents (US7077153 and US6606963) filed by the inventor (Brian Wynne) and held by Sharkstopper LLC, the device emits pulsed sounds in the frequency range of $30-500 \mathrm{~Hz}$ or $200-1500 \mathrm{~Hz}$, and is claimed to deter a variety of sharks including S. acanthias and N. brevirostris (Sharkstopper 2010). It is important to note that sharks quickly habituate to both attractive and repulsive sounds (Myrberg et al. 1969; Myrberg et al. 1978), which would mean that for any auditory-based shark repellent to remain effective it would have to be deployed only for short durations rather than being left on permanently.

\section{FUTURE DIRECTIONS}

"Practical problems are occasionally solved by freak discoveries, but the history of technology has shown repeatedly that advancements are most rapid and effective when a proper background in 
information and theory is available. When the need is complex, as, for instance, when an adequate system of protection against predatory sharks is desired, suitable answers are more likely to be found by theoretical advances than by trial and error 'practical solutions." (Gilbert 1963).

While our knowledge of the basic neurobiology and behavior of sharks is more extensive than it was when the first attempts to develop shark repellents were made, we are still some way away from a complete understanding of the sensory cues that drive their feeding behaviors. Many questions regarding the motivation behind a shark's decision to bite a human remain unanswered. For example, are the majority of shark bites a case of mistaken identity, where the shark has confused sensory cues emitted by a swimming human with those emitted by a more typical prey item such as a seal, or are sharks just not discerning diners and consider all animals in the ocean to be potential food? There may be no simple answers to such questions, but a more detailed understanding of the sensory biology and ecology of sharks will undoubtedly help us to better interpret and predict their behaviors when presented with a novel stimulus, whether that is a human SCUBA diver or a long line hook. Areas ripe for further investigation include the identification of visual cues (especially contrast and motion) used by sharks to detect and identify potential prey items, the identification of semiochemicals that have inherent biological meaning for sharks in terms of predator avoidance, and the integration of multi-sensory information in the brain that ultimately drives behavioral output.

Sharks are behaviorally complex animals and humans interact with sharks under a range of different scenarios. Thus, a single simple repellent device may not be achievable and combinations of repellents that manipulate a range of behaviors or sensory systems may prove to be more effective. For example, personal repellent devices might combine electrical fields and flashing lights, and areabased repellents might combine bubble curtains with controlled delivery of semiochemical odors. Combinations of visual and auditory stimuli have proved to be particularly effective as behavioral control measures in teleost fishes (Popper \& Carlson 1998). It may also be worthwhile taking a 'pushpull' approach to deterring sharks, i.e., deploying repellents in the immediate area of risk where the shark has strayed while simultaneously deploying attractant sounds or chemicals at a distant location to help draw the sharks away; such an approach is well established in the control of insect pests (e.g., 
Cook et al. 2007). Of course, it is also crucial to consider any potential adverse effects that shark repellent technologies might have on other ocean inhabitants, an issue that places serious constraints on the use of chemical or acoustic repellents, for example.

In addition to a better understanding of shark neurobiology, many of the future challenges in developing shark repellents are technological or economic in nature. It is one thing to establish that sharks are deterred by a strong electrical or magnetic field, but quite another to adapt such technology to protect an ocean beach subject to the continual actions of tides and waves, or to reduce shark bycatch and depredation in commercial fisheries. In each case, the costs and practical difficulties of deploying repellents must be weighed against the need to protect the lives of humans or sharks. However, in a world that is increasingly aware of the plight of sharks, yet simultaneously exploiting them in increasing numbers, the need to develop cheap, harmless, and effective shark repellents has never been more urgent.

\section{ACKNOWLEDGEMENTS}

The authors would like to express their gratitude to Professor Jiakun Song, Professor Arthur Popper and The Shanghai Oceans University for the opportunity to attend and present work related to this publication at the Sensory World of Fish and Fisheries conference in 2012. NSH and SPC are supported by The University of Western Australia, The Western Australian State Government, The Sea World Research and Rescue Foundation, and the Australian Research Council. 


\section{REFERENCES}

Andres KH, von Düring M (1988). Comparative anatomy of vertebrate electroreceptors. Progress in Brain Research 74, 113-31.

ASTM (2007). ASTM Standard A1054. Standard specification for sintered ceramic ferrite permanent magnets. ASTM International, West Conshohocken, PA.

Atkinson CJL, Collin SP (2010). Taste: vertebrates. In: Breed MD, Moore J, eds. Encyclopedia of Animal Behavior. Volume 3. Academic Press, Oxford, pp. 386-93.

Atkinson CJL, Collin SP (2012). Structure and topographic distribution of oral denticles in elasmobranch fishes. Biological Bulletin 222(1), 26-34.

Baldridge HD, Jr. (1974). Shark attack: a program of data reduction and analysis. Mote Technical Report No. A-1974. Contributions from the Mote Marine Laboratory, Volume 1, Number 2. Mote Marine Laboratory, Sarasota, FL.

Baldridge HD, Jr. (1990). Shark repellent: not yet, maybe never. Military Medicine 155(8), 358-61.

Blaxter JHS (1987). Structure and development of the lateral line. Biological Reviews 62(4), 471-514.

Bodznick D, Northcutt RG (1980). Segregation of electro- and mechano-receptive inputs to the elasmobranch medulla. Brain Research 195(2), 313-21.

Boord RL, Campbell CBG (1977). Structural and functional organization of the lateral line system of sharks. American Zoologist 17(2), 431-41.

Bozzano A, Murgia R, Vallerga S, Hirano J, Archer S (2001). The photoreceptor system in the retinae of two dogfishes, Scyliorhinus canicula and Galeus melastomus: possible relationship with depth distribution and predatory lifestyle. Journal of Fish Biology 59(5), 1258-78.

Bretschneider F, van den Berg AV, Peters RC (2001). Mechanoreception: hearing and lateral line. In: Kapoor BG, Hara TJ, eds. Sensory Biology of Jawed Fishes: New Insights. Science Publisher, Inc., Enfield (NH), pp. 215-53.

Brill R, Bushnell P, Sundaram R et al. (2009). The repulsive and feeding-deterrent effects of electropositive metals on juvenile sandbar sharks (Carcharhinus plumbeus). Fishery Bulletin 107(3), 298-307. 
Brown BR, Hughes ME, Russo C (2005). Infrastructure in the electric sense: admittance data from shark hydrogels. Journal of Comparative Physiology A: Neuroethology, Sensory, Neural, and Behavioral Physiology 191(2), 115-23.

Brown TW (1973). Sharks--The search for a repellent. Angus and Robertson, Sydney, Australia. Burden WD (1945). Development of a shark deterrent. Air Surgeon's Bulletin 2(10), 344-7. Carlström D (1963). A crystallographic study of vertebrate otoliths. Biological Bulletin 125(3), 44163.

Casper BM, Mann DA (2006). Evoked potential audiograms of the nurse shark (Ginglymostoma cirratum) and the yellow stingray (Urobatis jamaicensis). Environmental Biology of Fishes 76(1), 101-8.

Casper BM, Mann DA (2007a). Dipole hearing measurements in elasmobranch fishes. Journal of Experimental Biology 210(1), 75-81.

Casper BM, Mann DA (2007b). The directional hearing abilities of two species of bamboo sharks. Journal of Experimental Biology 210(3), 505-11.

Casper BM, Mann DA (2009). Field hearing measurements of the Atlantic sharpnose shark Rhizoprionodon terraenovae. Journal of Fish Biology 75(10), 2768-76.

Clark E (1974). The Red Sea's sharkproof fish. National Geographic Magazine 146, 718-27. Clark E (1983). Shark repellent effect of the Red Sea Moses sole. In: Zahurance BJ, ed. Shark Repellents from the Sea: New Perspectives. Westview Press, Boulder, CO, pp. 135-50.

Clark E, Chao S (1973). A toxic secretion from the Red Sea flatfish Pardachirus marmoratus (Lacépède). Sea Fisheries Research Station Bulletin 60, 53-6.

Clark E, George A (1979). Toxic soles, Pardachirus marmoratus from the Red Sea and P. pavoninus from Japan, with notes on other species. Environmental Biology of Fishes 4(2), 103-23.

Clarke SC, McAllister MK, Milner-Gulland EJ et al. (2006). Global estimates of shark catches using trade records from commercial markets. Ecology Letters 9(10), 1115-26.

Cliff G, Dudley SFJ (1992). Protection against shark attack in South Africa, 1952-90. Marine and Freshwater Research 43(1), 263-72. 
Clifford CWG, Ibbotson MR (2002). Fundamental mechanisms of visual motion detection: models, cells and functions. Progress in Neurobiology 68(6), 409-37.

Clusin WT, Bennett MV (1977). Calcium-activated conductance in skate electroreceptors: current clamp experiments. Journal of General Physiology 69(2), 121-43.

Cohen JL (1980). Functional organization of the retina of the lemon shark (Negaprion brevirostris, Poey): an anatomical and electrophysiological approach. PhD thesis University of Miami

Collin SP (2012). The neuroecology of cartilaginous fishes: sensory strategies for survival. Brain Behavior and Evolution 80(2), 80-96.

Collin SP, Pettigrew JD (1989). Quantitative comparison of the limits on visual spatial resolution set by the ganglion cell layer in twelve species of reef teleosts. Brain Behavior and Evolution 34(3), 184-92.

Cook SM, Khan ZR, Pickett JA (2007). The use of push-pull strategies in integrated pest management. Annual Review of Entomology 52(1), 375-400.

Corwin JT (1977). Morphology of the macula neglecta in sharks of the genus Carcharhinus. Journal of Morphology 152(3), 341-61.

Corwin JT (1981). Peripheral auditory physiology in the lemon shark: evidence of parallel otolithic and non-otolithic sound detection. Journal of Comparative Physiology A: Neuroethology, Sensory, Neural, and Behavioral Physiology 142(3), 379-90.

Crescitelli F (1990). Adaptations of visual pigments to the photic environment of the deep sea. Journal of Experimental Zoology 256(S5), 66-75.

Crescitelli F, McFall-Ngai M, Horwitz J (1985). The visual pigment sensitivity hypothesis: further evidence from fishes of varying habitats. Journal of Comparative Physiology A:

Neuroethology, Sensory, Neural, and Behavioral Physiology 157(3), 323-33.

Crognale MA, Levenson D, Pongais PJ, Deegan 2nd JF, Jacobs GH (1998). Cone spectral sensitivity in the harbor seal (Phoca vitulina) and implications for color vision. Canadian Journal of Zoology 76(11), 2114-8. 
Crooks N, Waring CP (2013). A study into the sexual dimorphisms of the Ampullae of Lorenzini in the lesser-spotted catshark, Scyliorhinus canicula (Linnaeus, 1758). Environmental Biology of Fishes 96(5), 585-90.

Daniel JF (1934). The Elasmobranch Fishes. The Univerisity of California Press, Berkeley, California.

Davies WL, Carvalho LS, Tay BH, Brenner S, Hunt DM, Venkatesh B (2009). Into the blue: gene duplication and loss underlie color vision adaptations in a deep-sea chimaera, the elephant shark Callorhinchus milii. Genome Research 19(3), 415-26.

Defense Do (2013). Shark deterrent technology (Shark Shield). [Cited 28 Oct 2013.] Available from: http://www.defence.gov.au/teamaustralia/shark_deterrent_technology_(Shark_Shield).htm

Denton EJ, Gray J (1983). Mechanical factors in the excitation of clupeid lateral lines. Proceedings of the Royal Society of London Series B: Biological Sciences 218(1210), 1-26.

Denton EJ, Shaw TI (1963). The visual pigments of some deep-sea elasmobranchs. Journal of the Marine Biological Association of the United Kingdom 43, 65-70.

Denton EJ, Warren FJ (1957). The photosensitive pigments in the retinae of deep-sea fish. Journal of the Marine Biological Association of the United Kingdom 36(3), 651-62.

Dijkgraaf S (1963). Functioning and significance of lateral line organs. Biological Reviews of the Cambridge Philosophical Society 38(1), 51-105.

Doak W (1974). Revolutionary weapon--anti-shark wet suit. Skin Diver 1974(June), 86-9.

Doyle J (1967). The 'Lorenzan sulphates'. A new group of vertebrate mucopolysaccharides. Biochemical Journal 103(2), 325-30.

Eckert MP, Zeil J (2001). Towards an ecology of motion vision. In: Zanker JM, Zeil J, eds. Motion Vision: Computational, Neural and Ecological Constraints. Springer, Berlin, pp. 333-69.

Eisthen HL (2004). The goldfish knows: olfactory receptor cell morphology predicts receptor gene expression. Journal of Comparative Neurology 477(4), 341-6.

Fahrenholz C (1915). Über die Verbreitung von Zahnbildungen und Sinnesorganen im Vorderdarm der Selachier und ihre phylogenetische Beurteilung. Jenaische Zeitschrift für Naturwissenschaft 53, 389-444. 
Fay RR, Kendall JI, Popper AN, Tester AL (1974). Vibration detection by the macula neglecta of sharks. Comparative Biochemistry and Physiology Part A: Physiology 47(4), 1235-40.

Fay RR, Popper AN (1974). Acoustic stimulation of ear of goldfish (Carassius auratus). Journal of Experimental Biology 61(1), 243-60.

Finger TE (1988). Organization of chemosensory systems within the brains of bony fishes. In: Atema J, Fay RR, Popper AN, Tavolga WN, eds. Sensory Biology of Aquatic Animals. SpringerVerlag, Berlin, pp. 339-63.

Finger TE (1997). Evolution of taste and solitary chemoreceptor cell systems. Brain Behavior and Evolution 50(4), 234-43.

Finger TE (2007). Evolution of taste. In: Kaas JH, Bullock TH, eds. Evolution of the Nervous System: A Comprehensive Reference. Volume 2. Non-mammalian Vertebrates. Elsevier/Academic Press, Amsterdam, pp. 423-41.

Fishelson L, Baranes A (1998). Distribution, morphology, and cytology of ampullae of Lorenzini in the Oman shark, Iago omanensis (Triakidae), from the Gulf of Aqaba, Red Sea. The Anatomical Record 251(4), 417-30.

Fogelberg JM (1944). Final report on the use of chemical materials as shark repellents. NRL Report No. P-2373. Naval Research Laboratory, Anacostia Station, Washington, D.C.

Fritsches KA, Brill RW, Warrant EJ (2005). Warm eyes provide superior vision in swordfishes. Current Biology 15(1), 55-8.

Fritsches KA, Marshall NJ, Warrant EJ (2003). Retinal specializations in the blue marlin: eyes designed for sensitivity to low light levels. Marine and Freshwater Research 54(4), 333-41.

Gardiner JM, Atema J (2007). Sharks need the lateral line to locate odor sources: rheotaxis and eddy chemotaxis. Journal of Experimental Biology 210(11), 1925-34.

Gardiner JM, Hueter RE, Maruska KP et al. (2012). Sensory physiology and behavior of elasmobranchs. In: Carrier JC, Musick JA, Heithaus MR, eds. Biology of Sharks and Their Relatives. CRC Press, Inc., Boca Raton, pp. 349-401.

Gilbert PW (1962). The behavior of sharks. Scientific American 207(1), 60-8.

Gilbert PW (1963). Sharks and Survival. DC Heath and Company, Boston, MA. 
Gilbert PW (1968). The use of the NUWC Shark Screen as a deterrent to sharks. Naval Undersea Warfare Center, Pasadena, CA.

Gilbert PW (1970). Studies on the anatomy, physiology, and behavior of sharks. Mote Technical Report No. A-1970b. Mote Marine Laboratory, Sarasota, FL.

Gilbert PW, Gilbert C (1973). Sharks and shark deterrents. Underwater Journal and Information Bulletin 5(2), 69-79.

Gillis JA, Modrell MS, Northcutt RG, Catania KC, Luer CA, Baker CVH (2012). Electrosensory ampullary organs are derived from lateral line placodes in cartilaginous fishes. Development 139(17), 3142-6.

Godin AC, Wimmer T, Wang JH, Worm B (2013). No effect from rare-earth metal deterrent on shark bycatch in a commercial pelagic longline trial. Fisheries Research 143(0), 131-5.

Griebel U, Schmid A (1992). Color vision in the California sea lion (Zalophus californianus). Vision Research 32(3), 477-82.

Griebel U, Schmid A (2002). Spectral sensitivity and color vision in the bottlenose dolphin (Tursiops truncatus). Marine and Freshwater Behaviour and Physiology 35(3), 129-37.

Gruber SH (1975). Duplex vision in the elasmobranchs: histological, electrophysiological and psychophysical evidence. In: Ali MA, ed. Vision in Fishes: New Approaches in Research. Plenum Press, New York and London, pp. 525-40.

Gruber SH, Gulley RL, Brandon J (1975). Duplex retina in seven elasmobranch species. Bulletin of Marine Science 25(3), 353-8.

Haine OS, Ridd PV, Rowe RJ (2001). Range of electrosensory detection of prey by Carcharhinus melanopterus and Himantura granulata. Marine and Freshwater Research 52(3), 291-6.

Hainke N (2010). Monster crocodile gobbles up a shark in Kakadu National Park. Herald Sun (June 24th 2010). Available from: http://www.heraldsun.com.au/news/monster-crocodile-gobbles-upa-shark-in-kakadu-national-park/story-e6frf7jo-1225883763532

Hama K, Yamada Y (1977). Fine structure of the ordinary lateral line organ. II. The lateral line canal organ of spotted shark, Mustelus manazo. Cell and Tissue Research 176(1), 23-36. 
Hanke FD, Peichl L, Dehnhardt G (2009). Retinal ganglion cell topography in juvenile Harbor Seals (Phoca vitulina). Brain Behavior and Evolution 74(2), 102-9.

Hansen A, Anderson KT, Finger TE (2004). Differential distribution of olfactory receptor neurons in goldfish: structural and molecular correlates. Journal of Comparative Neurology 477(4), 34759.

Hanson M, Westerberg H, Öblad M (1990). The role of magnetic statoconia in dogfish (Squalus acanthias). Journal of Experimental Biology 151(1), 205-18.

Harris AJ (1965). Eye movements of the dogfish Squalus acanthias L. Journal of Experimental Biology 43(1), 107-30.

Hart NS, Lisney TJ, Collin SP (2006). Visual communication in elasmobranchs. In: Ladich F, Collin SP, Moller P, Kapoor BG, eds. Communication in Fishes. Science Publishers, Inc., Enfield, NH, pp. 337-92.

Hart NS, Lisney TJ, Marshall NJ, Collin SP (2004). Multiple cone visual pigments and the potential for trichromatic colour vision in two species of elasmobranch. Journal of Experimental Biology 207(26), 4587-94.

Hart NS, Theiss SM, Harahush BK, Collin SP (2011). Microspectrophotometric evidence for cone monochromacy in sharks. Naturwissenschaften 98, 193-201.

Hashimoto Y (1979). Marine Toxins and Other Bioactive Marine Metabolites. Japan Scientific Societies Press, Tokyo.

Hodgson ES, Mathewson RF (1978). Electrophysiological studies of chemoreception in elasmobranchs. In: Hodgson ES, Mathewson RF, eds. Sensory Biology of Sharks, Skates, and Rays. U.S. Government Printing Office, Washington, D.C., pp. 227-67.

Hodgson ES, Mathewson RF, Gilbert PW (1967). Electroencephalographic studies of chemoreception in sharks. In: Gilbert PW, Mathewson RF, Rall DP, eds. Sharks, Skates and Rays. Johns Hopkins Press, Baltimore, MD pp. 491-501.

Horodysky AZ, Brill RW, Warrant EJ, Musick JA, Latour RJ (2008). Comparative visual function in five sciaenid fishes inhabiting Chesapeake Bay. Journal of Experimental Biology 211(22), $3601-12$. 
Hudspeth AJ, Corey DP (1977). Sensitivity, polarity, and conductance change in response of vertebrate hair cells to controlled mechanical stimuli. Proceedings of the National Academy of Sciences, USA 74(6), 2407-11.

Hueter RE (1990). Adaptations for spatial vision in sharks. Journal of Experimental Zoology 256(S5), $130-41$

Hunt JJ (1992). Morphological characteristics of otoliths for selected fish in the Northwest Atlantic. Journal of Northwest Atlantic Fishery Science 13, 63-75.

Hurley GV, Stone HH, Lemon DW (1987). The dogfish scourge: protecting fishing gear from shark attack. Canadian Industry Report of Fisheries and Aquatic Sciences No. 180. Department of Fisheries and Oceans, Halifax, Nova Scotia, Canada.

Hutchinson M, Wang JH, Swimmer Y et al. (2012). The effects of a lanthanide metal alloy on shark catch rates. Fisheries Research 131-133, 45-51.

Huveneers C, Rogers PJ, Semmens JM et al. (2013). Effects of an electric field on white sharks: in situ testing of an electric deterrent. PLoS One 8(5), e62730.

Imre I, Brown GE, Bergstedt RA, McDonald R (2010). Use of chemosensory cues as repellents for sea lamprey: potential directions for population management. Journal of Great Lakes Research 36(4), 790-3.

Johnsen PB, Teeter JH (1985). Behavioral responses of bonnethead sharks (Sphyrna tiburo) to controlled olfactory stimulation. Marine Behaviour and Physiology 11(4), 283-91.

Johnson CS, Scronce BL, McManus MW (1984). Detection of DC electric dipoles in background fields by the nurse shark. Journal of Comparative Physiology A: Neuroethology, Sensory, Neural and Behavioral Physiology 155(5), 681-7.

Johnson SE (1917). Structure and development of the sense organs of the lateral canal system of Selachians (Mustelus canis and Squalus acanthias). Journal of Comparative Neurology 28(1), $1-74$.

Jordan LK, Kajiura SM, Gordon MS (2009a). Functional consequences of structural differences in stingray sensory systems. Part I: Mechanosensory lateral line canals. Journal of Experimental Biology 212(19), 3037-43. 
Jordan LK, Kajiura SM, Gordon MS (2009b). Functional consequences of structural differences in stingray sensory systems. Part II: Electrosensory system. Journal of Experimental Biology 212(19), 3044-50.

Jordan LK, Mandelman JW, Kajiura SM (2011). Behavioral responses to weak electric fields and a lanthanide metal in two shark species. Journal of Experimental Marine Biology and Ecology 409(1-2), 345-50.

Jordan LK, Mandelman JW, McComb DM, Fordham SV, Carlson JK, Werner TB (2013). Linking sensory biology and fisheries bycatch reduction in elasmobranch fishes: a review with new directions for research. Conservation Physiology 1(1), cot002.

Kaimmer S, Stoner AW (2008). Field investigation of rare-earth metal as a deterrent to spiny dogfish in the Pacific halibut fishery. Fisheries Research 94(1), 43-7.

Kajiura SM, Holland KN (2002). Electroreception in juvenile scalloped hammerhead and sandbar sharks. Journal of Experimental Biology 205(23), 3609-21.

Kalmijn AJ (1971). The electric sense of sharks and rays. Journal of Experimental Biology 55(2), $371-83$.

Kalmijn AJ (1972). Bioelectric fields in seawater and the function of the ampullae of Lorenzini in elasmobranch fishes. Scripps Institution of Oceanography Reference Series, Contribution No. $72-83$.

Kalmijn AJ (1978). Electric and magnetic sensory world of sharks, skates and rays. In: Hodgson ES, Mathewson RF, eds. Sensory biology of Sharks, Skates and Rays. U.S. Government Printing Office, Washington, D.C., pp. 507-28.

Kalmijn AJ (1982). Electric and magnetic field detection in elasmobranch fishes. Science 218(4575), 916-8.

Kalmijn AJ (1989). Functional evolution of lateral line and inner ear sensory systems. In: Coombs S, Görner P, Münz H, eds. The Mechanosensory Lateral Line: Neurobiology and Evolution. Springer, New York, pp. 187-215.

Kasumyan AO, Døving KB (2003). Taste preferences in fishes. Fish and Fisheries 4(4), 289-347. 
Kempster RM, Garza-Gisholt E, Egeberg CA, Hart NS, O'Shea OR, Collin SP (2013a). Sexual dimorphism of the electrosensory system: a quantitative analysis of nerve axons in the dorsal anterior lateral line nerve of the blue-spotted fantail stingray (Taeniura lymma). Brain Behavior and Evolution 81(4), 226-35.

Kempster RM, Hart NS, Collin SP (2013b). Survival of the stillest: predator avoidance in shark embryos. PLoS One 8(1), e52551.

Kempster RM, McCarthy ID, Collin SP (2012). Phylogenetic and ecological factors influencing the number and distribution of electroreceptors in elasmobranchs. Journal of Fish Biology 80(5), 2055-88.

Kermeliotis T (2013). Boy scares off lions with flashy invention. [Cited 28 Oct 2013.] Available from: http://edition.cnn.com/2013/02/26/tech/richard-turere-lion-lights/index.html?hpt=hp_c2

Klimley AP, Myrberg JAA (1979). Acoustic stimuli underlying withdrawal from a sound source by adult lemon sharks, Negaprion brevirostris (Poey). Bulletin of Marine Science 29(4), 447-58.

KZNSB (2011). Electrical shark repellent. [Cited 28 Oct 2013.] Available from: http://www.shark.co.za/ElectricalRepellant

Ladich F, Popper AN (2004). Parallel evolution in fish hearing organs. In: Manley GA, Popper AN, Fay RR, eds. Evolution of the Vertebrate Auditory System. Springer, New York, pp. 95-127. Last PR, Stevens JD (2009). Sharks and Rays of Australia, 2nd edn. CSIRO, Melbourne. Laverack MS (1988). The diversity of chemoreceptors. In: Atema J, Fay RR, Popper AN, Tavolga WN, eds. Sensory Biology of Aquatic Animals. Springer-Verlag, New York, pp. 287-312. Lipschitz DL, Michel WC (2002). Amino acid odorants stimulate microvillar sensory neurons. Chemical Senses 27(3), 277-86.

Lisney TJ, Bennett MB, Collin SP (2007). Volumetric shift of sensory brain areas indicates ontogenetic shifts in the relative importance of sensory systems in elasmobranchs. Raffles Bulletin of Zoology Supplement 14, 7-15.

Lisney TJ, Collin SP (2007). Relative eye size in elasmobranchs. Brain Behavior and Evolution 69(4), 266-79. 
Lisney TJ, Collin SP (2008). Retinal ganglion cell distribution and spatial resolving power in elasmobranchs. Brain Behavior and Evolution 72(1), 59-77.

Lisney TJ, Theiss SM, Collin SP, Hart NS (2012). Vision in elasmobranchs and their relatives: 21st century advances. Journal of Fish Biology 80(5), 2024-54.

Litherland L, Collin SP (2008). Comparative visual function in elasmobranchs: spatial arrangement and ecological correlates of photoreceptor and ganglion cell distributions. Visual Neuroscience 25(4), 549-61.

Loew ER, McFarland WN, Margulies D (2002). Developmental changes in the visual pigments of the yellowfin tuna, Thunnus albacares. Marine and Freshwater Behaviour and Physiology 35(4), 235-46.

Lowenstein O, Roberts TDM (1951). The localization and analysis of the responses to vibration from the isolated elasmobranch labyrinth. A contribution to the problem of the evolution of hearing in vertebrates. Journal of Physiology 114(4), 471-89.

Lu J, Fishman HM (1994). Interaction of apical and basal membrane ion channels underlies electroreception in ampullary epithelia of skates. Biophysical Journal 67(4), 1525-33.

Lychakov DV, Boyadzhieva-Mikhailova A, Christov I, Evdokimov II (2000). Otolithic apparatus in Black Sea elasmobranchs. Fisheries Research 46(1-3), 27-38.

Lythgoe JN, Dartnall HJ (1970). A "deep sea rhodopsin" in a mammal. Nature 227(5261), 955-6.

Maditla N (2013). 'Friendlier’ shark barrier designed by SA boffins. IOL Scitech (14th May 2013). Available from: http://www.iol.co.za/scitech/science/environment/friendlier-shark-barrierdesigned-by-sa-boffins-1.1515659

Madsen C (1976). Tests for color discrimination and spectral sensitivity in the bottlenose dolphin, Tursiops truncatus. PhD thesis, University of Hawaii at Manoa, $129 \mathrm{pp}$.

Maisey JG (2001). Remarks on the inner ear of elasmobranchs and its interpretation from skeletal labyrinth morphology. Journal of Morphology 250(3), 236-64.

Maruska KP (2001). Morphology of the mechanosensory lateral line system in elasmobranch fishes: ecological and behavioral considerations. Environmental Biology of Fishes 60(1-3), 47-75. 
Maruska KP, Tricas TC (2004). Test of the mechanotactile hypothesis: neuromast morphology and response dynamics of mechanosensory lateral line primary afferents in the stingray. Journal of Experimental Biology 207(20), 3463-76.

Mass AM, Supin AY (2002). Visual field organization and retinal resolution of the beluga, Delphinapterus leucas (Pallas). Aquatic Mammals 28(3), 241-50.

Masseck OA, Hoffmann K-P (2008). Responses to moving visual stimuli in pretectal neurons of the small-spotted dogfish (Scyliorhinus canicula). Journal of Neurophysiology 99(1), 200-7.

Masseck OA, Hoffmann K-P (2009). Comparative neurobiology of the optokinetic reflex. Annals of the New York Academy of Sciences 1164(1), 430-9.

McComb DM, Frank TM, Hueter RE, Kajiura SM (2010). Temporal resolution and spectral sensitivity of the visual system of three coastal shark species from different light environments. Physiological and Biochemical Zoology 83(2), 299-307.

McComb DM, Tricas TC, Kajiura SM (2009). Enhanced visual fields in hammerhead sharks. Journal of Experimental Biology 212(24), 4010-8.

McCormick HW (1963). Shadows in the Sea: The Sharks, Skates and Rays. Chilton Book Company, Philadelphia, PA.

McCutcheon SM, Kajiura SM (2013). Electrochemical properties of lanthanide metals in relation to their application as shark repellents. Fisheries Research 147, 47-54.

McFadden EB, Johnson CS (1978). Color and reflectivity of sea-survival equipment as related to shark attack. Report FAA-AM-78-1. In: McFadden EB, ed. Flotation and Survival Equipment Studies. FAA Civil Aeromedical Institute, Oklahoma City, OK, pp. 41-5.

McFarland WN (1971). Cetacean visual pigments. Vision Research 11(10), 1065-76.

McFarland WN (1990). Light in the sea: the optical world of elasmobranchs. Journal of Experimental Zoology 256(S5), 3-12.

McFarland WN, Loew ER (1983). Wave produced changes in underwater light and their relations to vision. Environmental Biology of Fishes 8(3-4), 173-84.

Meredith TL, Caprio J, Kajiura SM (2012). Sensitivity and specificity of the olfactory epithelia of two elasmobranch species to bile salts. Journal of Experimental Biology 215(15), 2660-7. 
Meredith TL, Kajiura SM (2010). Olfactory morphology and physiology of elasmobranchs. Journal of Experimental Biology 213(20), 3449-56.

Meredith TL, Kajiura SM, Hansen A (2013). The somatotopic organization of the olfactory bulb in elasmobranchs. Journal of Morphology 274(4), 447-55.

Mills M, Rasch R, Siebeck UE, Collin SP (2011). Exogenous material in the inner ear of the adult Port Jackson shark, Heterodontus portusjacksoni (Elasmbranchii). The Anatomical Record 294(3), 373-8.

MMPA (n.d.). Standard specifications for permanent magnet materials. MMPA Standard No. 010000. Magnetic Materials Producers Association, Chicago, IL.

Montgomery J, Coombs S, Halstead M (1995). Biology of the mechanosensory lateral line in fishes. Reviews in Fish Biology and Fisheries 5(4), 399-416.

Montgomery JC, Baker CF, Carton AG (1997). The lateral line can mediate rheotaxis in fish. Nature 389(6654), 960-3.

Munz FW (1958). Photosensitive pigments from the retinas of certain deep-sea fishes. Journal of Physiology 140(2), 220-35.

Murray RW (1962). The response of the ampullae of Lorenzini of elasmobranchs to electrical stimulation. Journal of Experimental Biology 39(1), 119-28.

Murray RW, Potts WTW (1961). Composition of endolymph, perilymph and other body fluids of elasmobranchs. Comparative Biochemistry and Physiology 2(1), 65-75.

Myrberg AA, Jr ., Ha SJ, Walewski S, Banbury JC (1972). Effectiveness of acoustic signals in attracting epipelagic sharks to an underwater sound source. Bulletin of Marine Science 22(4), 926-49.

Myrberg AA, Jr., Banner A, Richard JD (1969). Shark attraction using a video-acoustic system. Marine Biology 2(3), 264-76.

Myrberg AA, Jr., Gordon CR, Klimley AP (1978). Rapid withdrawal from a sound source by openocean sharks. Journal of the Acoustical Society of America 64(5), 1289-97.

Nelson DR (1967). Hearing thresholds, frequency discrimination, and acoustic orientation in the lemon shark, Negaprion brevirostris (Poey). Bulletin of Marine Science 17(3), 741-68. 
Nelson DR (1983). Shark attack and repellency research: an overview. In: Zahuranec BJ, ed. Shark Repellents from the Sea. New Perspectives. AAAS Selected Symposium 83. Westview Press, Inc., Boulder, CO, pp. 11-74.

Nelson DR, Gruber SH (1963). Sharks: attraction by low-frequency sounds. Science 142(3594), 9757.

Nelson DR, Strong WR (1996). Chemical repellent tests on white sharks, with comments on repellent delivery methods. In: Klimley A, Ainley DG, eds. Great White Sharks: The Biology of Carcharodon carcharias. Academic Press, San Diego, CA, pp. 471-5.

Newman LA, Robinson PR (2005). Cone visual pigments of aquatic mammals. Visual Neuroscience 22(6), 873-9.

Northcutt RG (1978). Brain organization in the cartilaginous fishes. In: Hodgson ES, Mathewson RF, eds. Sensory Biology of Sharks, Skates and Rays. US Government Printing Office, Washington D.C., pp. 117-93.

O'Connell CP, Abel DC, Rice PH, Stroud EM, Simuro NC (2010). Responses of the southern stingray (Dasyatis americana) and the nurse shark (Ginglymostoma cirratum) to permanent magnets. Marine and Freshwater Behaviour and Physiology 43(1), 63-73.

O'Connell CP, Abel DC, Gruber SH, Stroud EM, Rice PH (2011a). Response of juvenile lemon sharks, Negaprion brevirostris, to a magnetic barrier simulating a beach net. Ocean and Coastal Management 54(3), 225-30.

O'Connell CP, Abel DC, Stroud EM, Rice PH (2011b). Analysis of permanent magnets as elasmobranch bycatch reduction devices in hook-and-line and longline trials. Fishery Bulletin 109(4), 394-401.

O'Connell CP, Andreotti S, Rutzen M, Meÿer M, He P (2013a). The use of permanent magnets to reduce elasmobranch encounter with a simulated beach net. 2. The great white shark (Carcharodon carcharias). Ocean \& Coastal Management In press.

O'Connell CP, He P, Joyce J, Stroud EM, Rice PH (2013b). Effects of the SMART'M (Selective Magnetic and Repellent-Treated) hook on spiny dogfish catch in a longline experiment in the Gulf of Maine. Ocean and Coastal Management In press. 
O'Connell CP, Stroud EM, He P (2013c). The emerging field of electrosensory and semiochemical shark repellents: mechanisms of detection, overview of past studies, and future directions. Ocean and Coastal Management In press.

O'Gower AK, Mathewson RF (1967). Spectral sensitivity and flicker-fusion frequency of the lemon shark, Negaprion brevirostris. In: Gilbert PW, Mathewson RF, Rall DP, eds. Sharks, Sskates and Rays. The Johns Hopkins Press, Baltimore, pp. 433-46.

Parker GH (1904). The function of the lateral line organ in fishes. Bulletin of the U. S. Bureau of Fisheries 24, 183-207.

Parker GH (1914). The directive influence of the sense of smell in the dogfish. Bulletin of the U.S. Bureau of Fisheries 33(798), 61-8.

Parker GH, Sheldon RE (1913). The sense of smell in fishes. Bulletin of the U. S. Bureau of Fisheries 32(775), 33-46.

Paulin MG (1995). Electroreception and the compass sense of sharks. Journal of Theoretical Biology 174(3), 325-39.

Paulin MG, Montgomery JC (1986). Elasmobranch eye motor dynamics characterized using pseudorandom stimulus. Journal of Comparative Physiology A: Neuroethology, Sensory, Neural and Behavioral Physiology 158(5), 723-8.

Peabody JE (1897). The ampullae of Lorenzini of the Selachii. Zoological Bulletin 1(4), 163-78.

Peach MB (2001). The dorso-lateral pit organs of the Port Jackson shark contribute sensory information for rheotaxis. Journal of Fish Biology 59(3), 696-704.

Peach MB (2003). The behavioural role of pit organs in the epaulette shark. Journal of Fish Biology 62(4), 793-802.

Peach MB, Marshall NJ (2000). The pit organs of elasmobranchs: a review. Philosophical Transactions of the Royal Society of London Series B: Biological Sciences 355(1401), 1131-4. Peach MB, Marshall NJ (2009). The comparative morphology of pit organs in elasmobranchs. Journal of Morphology 270(6), 688-701.

Peach MB, Rouse GW (2004). Phylogenetic trends in the abundance and distribution of pit organs of elasmobranchs. Acta Zoologica 85(4), 233-44. 
Peichl L, Behrmann G, Kröger RHH (2001). For whales and seals the ocean is not blue: a visual pigment loss in marine mammals. European Journal of Neuroscience 13, 1520-8.

Peters RC, Evers HP (1985). Frequency selectivity in the ampullary system of an elasmobranch fish (Scyliorhinus canicula). Journal of Experimental Biology 118(1), 99-109.

Pietrzakowski R, Imre I, Brown GE (2013). The behavioural response of migratory sea lamprey (Petromyzon marinus) to potential damage-released larval and migratory chemical alarm cues. Journal of Great Lakes Research 39(2), 234-8.

Popper AN, Carlson TJ (1998). Application of sound and other stimuli to control fish behavior.

Transactions of the American Fisheries Society 127(5), 673-707.

Popper AN, Fay RR (1977). Structure and function of the elasmobranch auditory system. American Zoologist 17(2), 443-52.

Popper AN, Fay RR, Platt C, Sand O (2003). Sound detection mechanisms and capabilities of teleost fishes. In: Collin SP, Marshall NJ, eds. Sensory Processing in Aquatic Environments. SpringerVerlag, New York, pp. 3-38.

Primor N (1983). Pardaxin produces sodium influx in the teleost gill-like opercular epithelia. Journal of Experimental Biology 105(1), 83-94.

Primor N (1985). Pharyngeal cavity and the gills are the target organ for the repellent action of pardaxin in shark. Experientia 41(5), 693-5.

Primor N, Parness J, Zlotkin E (1978). Pardaxin: the toxic factor from the skin secretion of the flat fish Pardachirus marmoratus (Soleidae). In: Rosenberg P, ed. Toxins: Animal, Plant and Microbial. Pergamon Press, New York, pp. 539-47.

Primor N, Zadunaisky JA, Murdaugh Jr HV, Boyer JL, Forrest Jr JN (1984). Pardaxin increases solute permeability of gills and rectal gland in the dogfish shark (Squalus acanthias). Comparative Biochemistry and Physiology Part C: Comparative Pharmacology 78(2), 483-90.

Primor N, Zlotkin E (1975). On the ichthyotoxic and hemolytic action of the skin secretion of the flatfish Pardachirus marmoratus (Soleidae). Toxicon 13(4), 227-31. 
Raschi WG, Aadlond C, Keithar ED (2001). A morphological and functional analysis of the ampullae of Lorenzini in selected galeoid sharks. In: Kapoor BG, Hara TJ, eds. Sensory Biology of Jawed Fishes: New Insights. Science Publishers, Inc., Enfield, NH, pp. 297-316.

Rasmussen LEL, Schmidt MJ (1992). Are sharks chemically aware of crocodiles? In: Doty RL, Müller-Schwarze D, eds. Chemical Signals in Vertebrates 6. Plenum Press, New York, pp. 33542.

Reichardt W (1961). Autocorrelation: a principle for the evaluation of sensory information by the central nervous system. In: Rosenblith WA, ed. Sensory Communication. MIT Press and John Wiley \& Sons, New York, London, pp. 303-17.

Retzius G (1881). Das Gehörorgan der Wirbelthiere: Morphologisch-histologische Studien. I. Das Gehörorgan der Fische und Amphibian. Samson and Wallin, Stockholm.

Reutter K (1992). Structure of the peripheral gustatory organ, represented by the siluroid fish, Plotosus lineatus (Thunberg). In: Hara TJ, ed. Fish Chemoreception. Chapman and Hall, London, pp. 60-78.

Reutter K, Boudriot F, Witt M (2000). Heterogeneity of fish taste bud ultrastructure as demonstrated in the holosteans Amia calva and Lepisosteus oculatus. Philosophical Transactions of the Royal Society of London Series B: Biological Sciences 355(1401), 1225-8.

Reutter K, Breipohl W, Bijvank GJ (1974). Taste bud types in fishes. Cell and Tissue Research 153(2), 151-65.

Rice PH (2008). A shocking discovery: how electropositive metals work and their effects on elasmobranchs. In: Swimmer Y, Wang JH, McNaughton LS, eds. Shark Deterrent and Incidental Capture Workshop, April 10-11, 2008. U. S. Department of Commerce, NOAA Technical Memorandum, NOAA-TM-NMFS-PIFSC-16, pp. 21-5.

Rigg DP, Peverell SC, Hearndon M, Seymour JE (2009). Do elasmobranch reactions to magnetic fields in water show promise for bycatch mitigation? Marine and Freshwater Research 60(9), 942-8. 
Robbins WD, Peddemors VM, Kennelly SJ (2011). Assessment of permanent magnets and electropositive metals to reduce the line-based capture of Galapagos sharks, Carcharhinus galapagensis. Fisheries Research 109(1), 100-6.

Rygg AD, Cox JPL, Abel R, Webb AG, Smith NB, Craven BA (2013). A computational study of the hydrodynamics in the nasal region of a hammerhead shark (Sphyrna tudes): implications for olfaction. PLoS One 8(3), e59783.

Sager DR, Hocutt CH, Stauffer JR, Jr. (1987). Estuarine fish responses to strobe light, bubble curtains and strobe light/bubble-curtain combinations as influenced by water flow rate and flash frequencies. Fisheries Research 5, 383-99.

SAMS (2013). Scientifically designed shark deterrent wetsuits and watersport products. [Cited 28 Oct 2013.] Available from: http://www.sharkmitigation.com/

Sand O, Enger PS, Karlsen HE, Knudsen F, Kvernstuen T (2000). Avoidance responses to infrasound in downstream migrating European silver eels, Anguilla anguilla. Environmental Biology of Fishes 57(3), 327-36.

Sato K, Suzuki N (2001). Whole-cell response characteristics of ciliated and microvillous olfactory receptor neurons to amino acids, pheromone candidates and urine in rainbow trout. Chemical senses 26(9), 1145-56.

Schaper A (1899). Die nervösen Elemente der Selachier-Retina in Methylenblaupräparaten. Nebst einigen Bemerkungen über das "Pigmentepithel" und die konzentrischen Stützzellen. Festschrift zum 70ten Geburtstag von Carl von Kupffer. Gustav Fischer, Jena, Germany, pp. 110.

Schieber NL, Collin SP, Hart NS (2012). Comparative retinal anatomy in four species of elasmobranch. Journal of Morphology 273(4), 423-40.

Schluessel V, Bennett MB, Bleckmann H, Blomberg S, Collin SP (2008). Morphometric and ultrastructural comparison of the olfactory system in elasmobranchs: the significance of structure-function relationships based on phylogeny and ecology. Journal of Morphology 269(11), 1365-86. 
Shai Y, Fox J, Caratsch C, Shih Y-L, Edwards C, Lazarovici P (1988). Sequencing and synthesis of pardaxin, a polypeptide from the Red Sea Moses sole with ionophore activity. FEBS letters 242(1), 161-6.

Sharkstopper (2010). Sharkstopper is the first and only acoustic shark repellent in the world. [Cited 28 Oct 2013.] Available from: http://www.thesharkstopper.com/index.html

Sisneros JA, Nelson DR (2001). Surfactants as chemical shark repellents: past, present, and future. Environmental Biology of Fishes 60(1-3), 117-30.

Smit CF, Peddemors V (2003). Estimating the probability of a shark attack when using an electric repellent. South African Statistical Journal 37, 59-78.

Smith ED (1974). Electro-physiology of the electrical shark-repellant. Transactions of the South African Institute of Electrical Engineers 65(8), 166-81.

Smith LE, O'Connell CP (2013). The effects of neodymium-iron-boron permanent magnets on the behaviour of the small spotted catshark (Scyliorhinus canicula) and the thornback skate (Raja clavata). Ocean \& Coastal Management In press.

Smith LJ (1991). The effectiveness of sodium lauryl sulphate as a shark repellent in a laboratory test situation. Journal of Fish Biology 38(1), 105-13.

Sobotka H (1965). Comparative biochemistry of marine animals. BioScience 15(9), 583-4.

Springer S (1955). Laboratory experiments with shark repellents. Proceedings of the Seventh Annual Gulf and Caribbean Fisheries Institute Coral Gables, FL, pp. 159-64.

Stein BE, Wallace MT, Stanford TR (2005). Brain mechanisms for synthesizing information from different sensory modalities. In: Goldstein EB, ed. Blackwell Handbook of Sensation and Perception. Blackwell Publishing Ltd, Malden, pp. 709-36.

Stoner AW, Kaimmer SM (2008). Reducing elasmobranch bycatch: laboratory investigation of rare earth metal and magnetic deterrents with spiny dogfish and Pacific halibut. Fisheries Research 92(2-3), 162-8.

Stroud E, Herrmann MM, Gruber SH (2005). Effects of magnetic fields exceeding 50 Gauss on tonically immobilized sharks. American Elasmobranch Society 21st Annual Meeting Tampa, Florida, USA. 6-12 July 2005 (available at http://elasmo.org/abst2005.php) 
Stroud EM, O'Connell CP, Rice PH et al. (2013). Chemical shark repellent: Myth or fact? The effect of a shark necromone on shark feeding behavior. Ocean and Coastal Management In press.

Tachibana K, Gruber SH (1988). Shark repellent lipophilic constituents in the defense secretion of the Moses sole (Pardachirus marmoratus). Toxicon 26(9), 839-53.

Tachibana K, Sakaitanai M, Nakanishi K (1984). Pavoninins: shark-repelling ichthyotoxins from the defense secretion of the Pacific sole. Science 226(4675), 703-5.

Tachibana K, Sakaitani M, Nakanishi K (1985). Pavoninins, shark-repelling and ichthyotoxic steroid n-acetylglucosaminides from the defense secretion of the sole Pardachirus pavoninus (Soleidae). Tetrahedron 41(6), 1027-37.

Tallack SML, Mandelman JW (2009). Do rare-earth metals deter spiny dogfish? A feasibility study on the use of electropositive "mischmetal" to reduce the bycatch of Squalus acanthias by hook gear in the Gulf of Maine. ICES Journal of Marine Science 66(2), 315-22.

Taylor V (1998). Testing the SharkPOD. Shark News. Newsletter of the IUCN Shark Specialist Group 11(July), pp. 10-11.

Tester AL (1963). Olfaction, gustation and the common chemical sense in sharks. In: Gilbert PW, ed. Sharks and Survival. D.C. Heath and Co., Boston, MA, pp. 255-82.

Tester AL, Kendall JI (1967). Innervation of free and canal neuromasts in the sharks Carcharhinus menisorrah and Sphyrna lewini. In: Cahn P, ed. Lateral Line Detectors. Indiana University Press, Bloomington, IN, pp. 53-69.

Tester AL, Kendall JI (1968). Cupulae in shark neuromasts: composition, origin, generation. Science 160(3829), 772-4.

Tester AL, Kendall JI, Milisen WB (1972). Morphology of the ear of the shark genus Carcharhinus, with particular reference to the macula neglecta. Pacific Science 26(3), 264-74.

Tester AL, Nelson GJ (1967). Free neuromasts (pit organs) in sharks. In: Gilbert PW, Mathewson RF, Rall DP, eds. Sharks, Skates and Rays. The Johns Hopkins Press, Baltimore,MD, pp. 503-31.

Tester AL, Nelson GJ, Daniels CI (1968). Test of NUWC shark attack deterrent device. NUWC TP 53. Naval Undersea Warefare Centre, Pasadena, CA. 
Theisen B, Zeiske E, Breucker H (1986). Functional morphology of the olfactory organs in the spiny dogfish (Squalus acanthias L.) and the small-spotted catshark (Scyliorhinus canicula (L.)). Acta Zoologica 67(2), 73-86.

Theiss SM, Collin SP, Hart NS (2010). Interspecific visual adaptations among wobbegong sharks (Orectolobidae). Brain Behavior and Evolution 76(3-4), 248-60.

Theiss SM, Collin SP, Hart NS (2011). Morphology and distribution of the ampullary electroreceptors in wobbegong sharks: implications for feeding behaviour. Marine Biology 158(4), 723-35.

Theiss SM, Collin SP, Hart NS (2012a). The mechanosensory lateral line system in two species of wobbegong shark (Orectolobidae). Zoomorphology 131(4), 339-48.

Theiss SM, Davies WIL, Collin SP, Hunt DM, Hart NS (2012b). Cone monochromacy and visual pigment spectral tuning in wobbegong sharks. Biology Letters 8(6), 1019-22.

Theiss SM, Hart NS, Collin SP (2009). Morphological indicators of olfactory capability in wobbegong sharks (Orectolobidae, Elasmobranchii). Brain Behavior and Evolution 73(2), 91101.

Theiss SM, Lisney TJ, Collin SP, Hart NS (2007). Colour vision and visual ecology of the bluespotted maskray, Dasyatis kuhlii Muller \& Henle, 1814. Journal of Comparative Physiology A: Neuroethology, Sensory, Neural and Behavioral Physiology 193(1), 67-79.

Thompson SA, Tachibana K, Nakanishi K, Kubota I (1986). Melittin-like peptides from the sharkrepelling defense secretion of the sole Pardachirus pavoninus. Science 233(4761), 341-3.

Tricas TC (1982). Bioelectric-mediated predation by swell sharks, Cephaloscyllium ventriosum. Copeia 1982(4), 948-52.

Tricas TC (2001). The neuroecology of the elasmobranch electrosensory world: why peripheral morphology shapes behavior. Environmental Biology of Fishes 60(1-3), 77-92.

Tricas TC, Kajiura SM, Summers AP (2009). Response of the hammerhead shark olfactory epithelium to amino acid stimuli. Journal of Comparative Physiology A: Neuroethology, Sensory, Neural and Behavioral Physiology 195(10), 947-54.

Van-Eyk SM, Siebeck UE, Champ CM, Marshall J, Hart NS (2011). Behavioral evidence for color vision in an elasmobranch. Journal of Experimental Biology 214(24), 4186-92. 
Vielma A, Ardiles A, Delgado L, Schmachtenberg O (2008). The elusive crypt olfactory receptor neuron: evidence for its stimulation by amino acids and cAMP pathway agonists. Journal of Experimental Biology 211(15), 2417-22.

Walls GL (1963). The Vertebrate Eye and Its Adaptive Radiation. Hafner Publishing Company, New York, London.

Wang JH, McNaughton LS, Swimmer Y (2008). Galapagos and sandbar shark aversion to electropositive metal (Pr-Nd alloy). In: Swimmer Y, Wang JH, McNaughton LS, eds. Shark Deterrent and Incidental Capture Workshop, April 10-11, 2008. U. S. Department of Commerce, NOAA Technical Memorandum, NOAA-TM-NMFS-PIFSC-16, pp. 28-32.

Wartzok D, McCormick MG (1978). Color discrimination by a Bering Sea spotted seal, Phoca largha. Vision Research 18(7), 781-4.

Whitear M, Moate RM (1994). Microanatomy of taste buds in the dogfish, Scyliorhinus canicula. Journal of Submicroscopic Cytology and Pathology 26(3), 357-67.

Whitley GP, Payne GH (1947). Testing a shark repellent. Australian Zoologist 11(2), 151-7.

Williams JR, Chai D, Gong H, Zhao W, Wright D (2002). Studies toward the synthesis of the shark repellent pavoninin-5. Lipids 37(12), 1193-5.

Worm B, Davis B, Kettemer L et al. (2013). Global catches, exploitation rates, and rebuilding options for sharks. Marine Policy 40, 194-204.

Yao M, Rosenfeld J, Attridge S, Sidhu S, Aksenov V, Rollo CD (2009). The ancient chemistry of avoiding risks of predation and disease. Evolutionary Biology 36(3), 267-81.

Yopak KE, Lisney TJ, Collin SP (2013). Not all sharks are "swimming noses": Variation in olfactory bulb size in cartilaginous fishes. Brain Structure and Function In press.

Zeiske E, Caprio J, Gruber SH (1986). Morphological and electrophysiological studies on the olfactory organ of the lemon shark, Negaprion brevirostris. In: Uyeno T, Arai R, Taniuchi T, Matsuura K, eds. Indo-Pacific Fish Biology: Proceedings of the Second International Conference on Indo-Pacific Fishes. Ichthyological Society of Japan, Tokyo, pp. 381-91.

Zlotkin E, Gruber SH (1984). Synthetic surfactants: a new approach to the development of shark repellents. Archives of Toxicology 56(1), 55-8. 